Jo Van Steenbergen*, Stijn Van Nieuwenhuyse*

\title{
Truth and Politics in Late Medieval Arabic Historiography: the Formation of Sultan Barsbāy's State (1422-1438) and the Narratives of the Amir Qurqumās al-Sha'bānī (d. 1438)
}

https://doi.org/10.1515/islam-2018-0006

\begin{abstract}
Throughout al-Ashraf Barsbāy's reign as sultan of Mamluk Egypt and Syria (1422-1438), one of the main performers and representatives of his expanding authority and power was the amir Qurqumās al-Sha'bānī (d. 1438). Defeated in the power struggle that followed sultan Barsbāy's death, Qurqumās' career ended dramatically in his execution by order of the new sultan, al-Zahir Jaqmaq (r. 1438-1453). Whereas this amir's rich case received substantial attention from the era's leading Egyptian historiographers, it has so far hardly attracted any interest in modern scholarship. This article aims to remedy this, but not simply in order to pursue some detailed reconstruction of Qurqumās' life story. It rather wishes to explore this story as a case study towards a better understanding of how extant historiographical narratives that mattered so much to Qurqumās' contemporaries may be read in analytically more meaningful ways than tradi-
\end{abstract}

Article note: This article has been finalised within the context of the project "The Mamlukisation of the Mamluk Sultanate II: Historiography, Political Order and State Formation in Fifteenth-Century Egypt and Syria" (UGent, 2017-21); this project has received funding from the European Research Council (ERC) under the European Union's Horizon 2020 research and innovation programme (Consolidator Grant agreement No 681510). The research leading to this article was first conducted within the framework of the project "The Mamlukisation of the Mamluk Sultanate: Political Traditions and State Formation in Fifteenth-century Egypt and Syria" (UGent, 2009-14, ERC Starting Grant agreement No 240865). Research data were mainly collected by Stijn Van Nieuwenhuyse; the argumentation and text were mainly assembled by Jo Van Steenbergen. An early version of this article was first presented as a paper at the Second Conference of the School of Mamlūk Studies (Liège, 25-27 June 2015). Our thanks are due to Frédéric Bauden, organiser of the SMS conference, for accepting our paper in the conference programme, and to the many conference participants and to colleagues in the Mamluk History and Culture research group at Ghent University for helpful feedback and comments.

*Corresponding authors: Jo Van Steenbergen, Universiteit Gent, Gent, Belgium, jo.vansteenbergen@ugent.be / Stijn Van Nieuwenhuyse, Universiteit Gent, Gent, Belgium, stijn.vannieuwenhuyse@ugent.be 
tional approaches have so far allowed for. The article therefore proposes and explores a two-tiered - social and cultural - method of reading contemporary historical texts as politically engaged narrative claims to historical truth. It is demonstrated how across a diverse set of narrative texts the high-profile career of the amir Qurqumās al-Sha'bānī appears as functionally constructed around the messy relational realities of the administration of sultan Barsbāy's justice and the performance of his warfare in Egypt, Syria, the Hijaz and Eastern Anatolia. It is furthermore argued that in the historiographical record of these messy realities Qurqumās' career is made to appear through the semantics of justice and sovereignty as an agent of the legitimate and truthful political order of the formation of sultan Barsbāy's state, but only for as long as that state existed.

Keywords: Arabic historiography, state formation, Mamluk Sultanate, al-Malik al-Ashraf Barsbāy, Qurqumās al-Sha'bānī, narrative construction, justice, warfare, political order, truth politics

Power, knowledge and time-space are highly fluid, deeply interconnected and mutually constitutive social phenomena that defy any simple explanations. This statement, at the same time self-evident and challenging, has certainly struck many chords in the long and rich tradition of Islamic studies. In the field of premodern Islamic history, and of its historiography in particular, the relational prism power/knowledge/time-space has for many decades informed new ways of looking at, and of operationalising, textual narrative source material for the study of, especially, the early period (7th-10th centuries). This has not yet happened in any parallel ways for the 'medieval' period of Islamic history (11th-15th centuries). Nevertheless, recent studies have demonstrated how, for understandings of this period too, moving beyond (very valuable and much needed) philological approaches and (often still remarkably positivist) traditional textual assumptions offer not just valid, but also highly necessary, ways forward. In the wider field of 'medieval' Islamic history, however, these historiographical insights' impact arguably remains slow-coming and peripheral. There remains therefore an urgent need for bridging this gap between 'medieval' historiographical and historical scholarship, and more generally between 'medieval' Islamic cultural and social history. This article wishes to engage with and follow up from those important pioneering steps, aiming to modestly contribute to the slow bridging of this gap. Introducing, and examining critically, the power/knowledge/time-space prism in the conceptual format of a politics of historical truth, this article proposes to read contemporary historical texts as relational narrative claims to particular truths in messy contexts of state formation, and to explore what new insights such a 
reading may entail. It will do so through a detailed case study, focusing on an era of substantial, even seminal, historiographical production and state formation in Egypt: the first decades of the 15th century CE. ${ }^{1}$

The case that this article engages with is that of Sayf al-Dīn Qurqumās al-Sha'bānī al-Ẓāhirī al-Nāṣirī Ahrām Dāgh (d. 1438). The 15th-century life and career of this mamlūk courtier, military commander, short-lived candidate for the Syro-Egyptian sultanate and executed rebel may be reconstructed from a relatively wide range of extant contemporary historiographical texts. The general biographical picture that thus emerges appears very much as a micro-history of military service and political empowerment that blends in seamlessly with the general corpus of mamlūk life stories that has survived for the long history of the so-called Mamluk Sultanate of late medieval Egypt and Syria (13th c.-1517). This default nature of Qurqumās' personal history probably explains why it has so far hardly attracted any attention in modern scholarship. Obviously, this lack of interest was not shared by contemporary Egyptian historians, who had many things to tell, both good and bad, about this amir and about his many actions during and shortly after the reign of sultan al-Malik al-Ashraf Barsbāy (r. 1422-1438).

As announced above, one of the main purposes of this article is to explore this particular historiographical material in much more analytical depth, not in order to pursue any positivist reconstruction of Qurqumās' traditional mamlūk past 'as it really used to be', but to understand better how, why and to what effect contemporary textual material concerning him was produced in those particular ways. This article is therefore not primarily concerned with recounting the personal history of the amir Qurqumās or for that matter with filling in any factual blanks in the careers of his more well-known contemporaries sultan al-Malik al-Ashraf Barsbāy (r. 1422-1438) and sultan al-Malik al-Ẓāhir Jaqmaq (r. 1438-1453). Working

1 See in this respect Konrad Hirschler's highly relevant call for the study of late medieval Arabic historiography to finally start moving "from source-criticism to the Cultural Turn", and in particular his conclusions that "... it is the best of cultural history that has achieved the bridging of the turn to meaning on the one hand with a dedicated interest in social processes on the other. There is no denial that to bridge this gap is difficult as social and cultural histories are to some degree incompatible. ... However ... the Cultural Turn allows us to consider Mamluk historiography, be it in its prosopographical or its chronistic form, as a richer genre of texts than either social or political history considered them to be. In other words, by moving beyond source-critical questions and seeing the texts as more than repositories of facts, narrative historiography can return to play a central role in driving the field of Mamluk Studies”. (HIRSCHLER 2013, 179-180). For the state of premodern Islamic historiographical studies more in general, see RoBINSON 2012; HIRSCHLER 2012. The admittedly vague notion of a power/knowledge/time-space prism resonates with thoughts and ideas formulated in, among many others, SAFI 2006 and FoUCAULT 1971. 
from the assumption that these and many other actors' micro-histories have mainly survived as narrative constructions by contemporary historians only, the article wishes to reconsider the value of these constructions for modern research. It proposes to rethink these narrative constructions in contemporary Arabic historiography as operating on a relational middle-ground that connects the stories circulating about political actors and their micro-histories to particular macro-historical social and cultural contexts. These contexts include late medieval Syro-Egyptian processes of state formation as well as contemporary discursive claims about those processes' historical trajectories. Seen from this perspective, this analysis of the narratives of Qurqumās' life and times is presented here first and foremost as an experimental case in point for the value and validity of a more analytical method of reading the densely written and voluminous chronographical and biographical Arabic texts from the later 'medieval' period. It will be demonstrated how the analytical depth that may thus be achieved in modern understandings of particular cases such as that of Qurqumās feeds back in highly informative ways into current understandings of the social and cultural contexts in which that case operated and acquired its historical meanings.

The article begins with an overview of the latter social and cultural contexts. This includes an explanation of the historicising way of reading historical texts as relational narrative claims to historical truth in messy political contexts that is being proposed here. This also requires a brief presentation of those texts and their authors, and especially of the multiplicity of historiographical voices that arose in these contexts around the stories about the life and adventures of the amir Qurqumās al-Sha'bānī. In the article's main, second and third parts, it is demonstrated how despite this multiplicity of voices the high-profile career of the amir Qurqumās appears coherently and comprehensively constructed across these texts around particular social and cultural claims to historical truth that were related to the long process of the formation of sultan al-Ashraf Barsbāy's state in Egypt, Syria and beyond, as well as to its quick transformation by sultan al-Z̄āhir Jaqmaq in 1438. Inspired by the priority given to symbolic and physical violence in the historical sociology of state formation and by the many shades of violence that colour many of the era's historical narratives, these claims are identified here as having been constructed around the two universal themes of the symbolic violence of justice and the physical violence of warfare. The social, relational dimensions of the engagements of Qurqumās' textual persona with these two themes are explored in the second part. The third part furthers this by zooming in on the cultural, semantic dimensions of these engagements. These social and cultural analyses arguably make it possible to appreciate and estimate in detail these particular narratives' meaningfulness and instrumentality for authors and audiences beyond any merely chronographic, descriptive function- 
alities. It is suggested here that this exposes the trajectory of sultan Barsbāy's sultanate as it was experienced in the socio-spatial realities of Egypt, Syria and beyond, and at the same time as it was claimed, explained and imagined by contemporaries, including by historians. Through this analytical lens Qurqumās actually appears in highly informative, revealing and arguably very new social and cultural ways, as one among a handful of important royal agents and performers of this particular social and cultural process of the successful but only short-lived consolidation and expansion of sultan Barsbāy's sultanate throughout the 1420s and 1430s, in the western regions of Muslim West-Asia and in the era's discursive (and historiographical) imaginations at the same time.

\section{Contexts: Early 15th-Century State Formation and Historical Truth Politics}

\section{Early 15th-century state formation}

As has been well established by now, the early decades of the 15th century were a time of substantial crisis and transformation for the political and other elites of the Syro-Egyptian Sultanate. These changes were in many ways caused by the longterm socio-economic effects of plague, pestilence and ecological misfortunes and by the brief but devastating conquest of Syria by Central-Asia's post-Mongol ruler Timur (1370-1405). In intricately connected ways, this crisis and transformation also had everything to do with the faltering and disputed leadership of sultan Faraj b. Barqūq (r. 1399-1412), with the concomitant conflictual fragmentation of the sultanate's political elites and with these factional conflicts' settlement in a process of Syrian 'territorialisation', during which factions entrenched in Syrian towns and cities and engaged in extremely violent and attritional warfare. ${ }^{2} \mathrm{Cul}-$ minating in the total loss of Egyptian control over Syrian elites and domains and in the public execution of sultan Faraj in Damascus in 1412, this was indeed an episode of immense changes in the region's history. In 1412 its main survivors, including above all the new sultan al-Mu'ayyad Shaykh (r. 1412-1421) and his supporters, were forced - or, depending on the perspective, had thus enforced a unique opportunity - to reconstruct the reality of the sultanate around their new positions and status, something which they pursued through the construction of

2 ONImUs 2013, 487-490. For a detailed study of the meanings of appointments to a post in Syria during this period, see ONIMUs 2015, 379-384. 
a new political elite in Egypt, the integration in a variety of old and new ways of diverse elites in Syria and Eastern Anatolia, and the overall restoration of Cairo's symbolic authority and regional hegemony. ${ }^{3}$

When Shaykh died in 1421, this process of restoration/formation was all but finished, and it was continued by his successors, albeit in their own transformative ways and relying on their own associates and supporters rather than on Shaykh's. Especially sultan al-Ashraf Barsbāy appears as having ruled long and successfully enough between 1422 and 1438 to reap some of the fruits of this policy of political restoration and state formation. As is relatively well-known, Barsbāy appears to have been very keen to extend his control and dominion over peripheral areas and over centrifugal forces, resulting in his very active engagements with the Red Sea and Hijāz areas and their commercial networks, with local rulers in southeast Anatolia, and also with the eastern Mediterranean, reducing the Lusignan Kingdom of Cyprus to tributary status in $1426 .{ }^{4}$ In these and many related activities that attest to the formation and enhancement of a new regional political order that was topped by sultan Barsbāy and that was emanating from his court in Cairo, all kinds of agents, representatives and supporters of the sultan and his court played a crucial role. As will be detailed below, one such role was played by the amir Qurqumās al-Sha 'bānī. Just as this Qurqumās, many of these agents, representatives and supporters had been around for quite a few years. As survivors of the transformations of 1412, many of them only entered into the limelight at the time of Barsbāy's empowerment in 1421-1422, a process that generated around Barsbāy's sultanate a new and increasingly coherent elite of mamlūk amirs and others that was to remain dominant in and beyond Cairo throughout the 1420s, 1430 s and 1440s. Whereas the larger contours of what actually happened in this timeframe are quite well established by now, not very much is understood so far of how that process of political integration and socio-political formation exactly evolved, nor of how, in 1438, its quick disintegration upon Barsbāy's death and its substantial transformation with Jaqmaq's accession played out. ${ }^{5}$

3 Loiseau 2010, 179-214; Martel-Thoumian 1991, 181-333.

4 DarRag 1961, 159-267; Meloy 2010, 113-139; Meloy 2003, 7-8; Wing 2015, 386; Wing 2014, 63; Apellániz 2009, 113-139; AdriaEnSSEns / VAN STEEnBERGEN 2016.

5 Van Steenbergen 2015, 19-23; VAn Steenbergen 2016 b, 57-65; Van Steenbergen / Wing / D’hulster 2016 a; VAN SteEnbergen / Wing / D'hulster 2016 b. 


\section{Early 15th-century politics of historical truth}

It is first and foremost in the many particularities of the various stories of a new elite's integration into Barsbāy's expanding order of things that important keys may be found for any deeper analysis and understanding of the formation and transformation of that new order and dominion. In fact, these stories have mainly been recorded, transmitted and narrated by equally important in- and outsiders to the same process of the formation of a new political and social order in and beyond Cairo. At least, a lot of the most detailed information that has survived for this historical period consists of exactly these stories, transformed to the status of collective, or cultural, memory in the narratives of the annalistic and dynastic chronicles and biographical dictionaries that were produced in the same period by members of Cairo's cultural and bureaucratic elites. ${ }^{6}$ Key historians for this period, such as Aḥmad b. 'Alī al-Maqrīzī (ca. 1365-1442), Badr al-Dīn Maḥmūd al-'Aynī (1361-1451), Aḥmad b. Hajar al-'Asqalānī (1372-1449) and their colleagues and students, were in many ways part and parcel of the substantially transformed elites that emerged after 1412. They all moreover variously participated in the new political order that was emerging around the court, establishing and performing it as leading scholars, judges and officials, or at least confirming and benefiting from it in their pursuance of patronage, intellectual impact and socio-cultural identity. Most importantly, these historians and their colleagues also participated through their many and voluminous writings in the ongoing construction and 'structuration' of a cultural order that aligned itself with (or occasionally also, in equally constitutive ways, against) the new social and political orders of the time. In their many and diverse writings, and above all in those that operate within a historiographical framework, they thus engaged in the timeframe's 'politics of historical truth'. By this we mean that they all actively participated in the imagination of a particular historical trajectory that somehow culminated in, and reflected in moralizing ways on, those social and political orders of their time, including importantly those of Sultan Barsbāy and the court to which many of them had been one way or another connected. ${ }^{7}$

\footnotetext{
6 On "transitions and transformations" that "account for the dynamics of cultural memory", see the theoretical introduction in ASSMANN 2008.

7 See Broadbridge 1999, 95-97; VAn SteEnbergen 2016a. This approach is heavily indebted to the model set in HIRSCHLER 2006, and more in general to the heuristic narratological practices of New Historicism as advocated by Stephen Greenblatt (see GreEnBlatT / GALlaGHER 2001); it owes its theoretical underpinnings to Michel Foucault's 'Nietschian' ideas about truth regimes, which are constituted from the historical relationship between truth and power (FoUCAULT 1971) (on the narratological connections between Greenblatt and Foucault, see PIETERS
} 
Against the discursive backdrop of these complex contemporary politics of historical truth, the many stories that have been transmitted in these works of history about the agents, partners and participants in the formation of Barsbāy's state and authority acquire a particular meaning and historical value. They are not merely selective and literary renderings of out- or insider observations. They are constructed, in practical and discursive ways, to participate in that same cognitive process from which the post-1412 appearances of social and political order emerged. These stories and, especially, the narrative texts that transmitted them are, therefore, historical actors in their own right, participating in a particular discourse and practice of the new post-1412 order that was constructed by, and that simultaneously constructed, the varying interests of the elites of the 1420s, '30s and "40s (including those of their own authors, but also by default of their readers and wider audiences). The many extant renderings of stories about Qurqumās al-Sha 'bānī, as one prominent member of those elites, therefore arguably inform not just about Qurqumās, but first and foremost about the formation of that new order and about the shared and conflicting claims that were made about its historical trajectory. Whereas the larger textual contexts of these stories' transmission have been relatively well established by now, also in this case not very much is understood of the particular discursive and practical relationships of their textual renderings with that new order, nor with its transformation in $1438 .^{8}$

\section{$\operatorname{Re} /$ constructing Qurqumās al-Sha'bānī}

The narrative building blocks and mechanisms by which fifteenth-century historians in Egypt, such as al-Maqrīzī, al-'Aynī, Ibn Ḥajar and some of their younger peers, actively participated in the construction of historical truth and socio-political order, and by which they simultaneously tried to have an impact on that process, gave shape to a multiplicity of voices that reflect their authors' differing positions and interests vis-à-vis these politics of historical truth. These authorial

\footnotetext{
2000). This notion of a politics of historical truth, finally, is also indebted to, and an analytical partner in, what Omid Safi identified as the politics of knowledge (see SAFI 2006).

8 See Hirschler 2013.

9 This is the textual, Arabized, version of the Turkic Qurqmas/Qorqmas/Qorqmaz/Korkmaz, "the fearless” (SAUVAGET 1950, 53: “qui ne craint pas”). In this paper, we will use the Arabized version because of our focus on the representations of this amir's persona in the Arabic texts first and foremost; Qurqumās is consciously considered here as a literary avatar of the historical Qurqmās, and it is our explicit choice to consider an engagement with that avatar more meaningful than any other approach.
} 
positions and interests also materialised in varying judgements on Qurqumās that emerge especially from the almost paradoxical contrast between the framing of his persona during the many years before sultan Barsbāy's death in June 1438 and for the handful of months thereafter, until his execution at the beginning of December of the same year. The latter in particular presents a useful starting point in this paper's endeavor to understand the wider meanings of a literarily constructed persona such as Qurqumās'. That construction will therefore be presented here in reversed order, moving from the brief but lethal interactions with sultan Jaqmaq in 1438 to the long and eventful years of loyal service to, especially, sultan Barsbāy before 1438.

\section{Qurqumās and sultan Jaqmaq: explaining rebellion, trial and punishment}

All the available historiographical material suggests that as a senior military leader and powerful courtier of many years, Qurqumās considered himself, or was considered by others, a valuable candidate for Barsbāy's succession. This royal ambition would have become apparent especially when the throne of Barsbāy's son was usurped, in September 1438, by one of Qurqumās' peers, who was to reign as al-Z̄āhir Jaqmaq (r. 1438-1453). Beyond the functional merits of service and leadership in Barsbāy's shadow, however, little is known about any other qualities or tools that may have been available to Qurqumās to boost his own claims to royal specialty and entitlement. With the slightly older sultans Țațar (r. August-November 1421) and Barsbāy, however, he did have his time as a mamlūk in the households of the turn-of-the century sultans Barqūq and his son Faraj in common. Qurqumās is also said to have been married to a daughter of the latter, which would have provided him with a royal lineage that was highly venerated among Barqūq's former mamlūks. It is furthermore also suggested that Qurqumās was married to a daughter of sultan al-Mu'ayyad Shaykh and that he had a male son with her. ${ }^{10}$ Although it is not known whether, how and when he operationalized such royal ties, they undoubtedly enhanced Qurqumās' status and standing among the elites of his time. Eventually, however, these particular merits proved of no avail, when his attempt to challenge Jaqmaq and usurp his freshly won throne failed. On Monday, 1 December 1438, Qurqumās was executed by decapi-

10 For the marriage with Faraj's daughter, see al-Jawharī, Nuzhat (1970-1994), 3, 126. For the marriage with Mu'ayyad Shaykh's daughter, see al-'Aynī, 'Iqd (1985-1989), 2, 542 and Ibn Ḥajar, Inb $\bar{a}^{\prime}$ (1986), 9, 89. 
tation, shortly after having been sentenced to death for treason against the new sultan. ${ }^{11}$

In the annalistic chronicle that presents a detailed account of Egypt's history from the years of its author's childhood to just before his death (773-850 $\mathrm{AH} / 1371-1446 \mathrm{CE})$, Inbā' al-Ghumr bi-Abnä' al-'Umr fī l-Tärīkh, Ibn Ḥajar (1372-1449) added a comprehensive summary report of Qurqumās' career to this story of how, in November-December 1438, order had been restored when Qurqumās stood trial for treason against Barsbāy's successor, sultan al-Z̄āhir Jaqmaq (r. 1438-1453), and was subsequently executed.

Qurqumās al-Sha'bānī was one of the mamlūks of al-Nāșir Faraj. Then all kinds of things happened to him, including his establishment as a junior executive secretary (dawādār șaghir) in the early days of the dawla of al-Ashraf [Barsbāy]. Then he was appointed to the amirate of Mecca, in a partnership with (sharīkan li-) Hasan b. 'Ajlān (sic). ${ }^{12}$ Then he returned to Cairo and he was appointed to the position of great chamberlain (hājib kabir), which he performed with vigour and rigour (bi-shahāma wa-șarāma); [in this capacity] he was revered [by all] (muhīban), he was favourably disposed to the jurisconsults (yamil ilā l-fuqah $\left.\bar{a}^{\prime}\right)$, whom he sat with [for consultation], and he studied books of religious knowledge (kutub al-ilm). Then he was appointed to the amirate of Aleppo, after the sultan's return from the Amid [campaign against the Aqquyunlu Turkmen (1433)]. Then he was dismissed from it, and he was established in Cairo as amīr of the council (amīr majlis). Then it so happened that al-Ashraf died while [Qurqumās] was with those who had been sent out in the Northern lands (al-bilād al-shimāliyya); when they returned, the strong man in the sultanate (al-qā'im fì l-salțana) was al-Malik al-Zāhir [Jaqmaq], who deposed al-'Azīz Yūsuf [b. Barsbāy] and arrested the amirs who had been on his side. It was not long before [Qurqumās] revolted (thāra) against al-Ẓāhir, together with the Ashrafiyya mamlūks. The amirs who were partners in the dawla of al-Z̄āhir (alladhīna kānū bi-dawlat al-Ẓāhir) fought him, until he was beaten. Some were wounded and others were killed. Eventually [the hiding Qurqumās and his followers] were taken and sent to Alexandria. ${ }^{13}$

This full summary of Qurqumās' life and career by Ibn Ḥajar reveals itself as an insightful, but also rather particular, textual construction, in which a series of very positive assessments about Qurqumās' maintenance of order during his

11 On the rebellion and the subsequent trial and execution see, respectively, al-Maqrīzì, Sulūk (1954-1972), 4, 1091-1094 and 1104-1105; Ibn Taghrībirdī, Nujūm (1909-1936), 7, 39-48 and 56-57; al-Jawharī, Nuzhat (1970-1994), 4, 29-33 and 55-56; al-'Aynī, 'Iqd (1985-1989), 2, 518-519 and 539-540; 'Abd al-Bāsiț, Nayl (2002), 5, 56-57 and 65; Ibn Iyās, Badā'i' (2010), 2, 201-202 and 205-206; Ibn Hajar, Inbā' (1986), 9, 51-52.

12 This should be 'Alī b. 'Inān, not Ḥasan b. 'Ajlān, who had actually been deposed shortly before Qurqumās arrived in Mecca and turned into a major opponent for Qurqumās and 'Alī. MELoy 2010, 118-121.

13 Ibn Hajar, Inbā' (1986), 9, 53. 
tenure as great chamberlain (including references to his vigour and rigour, his reverence, his consultation of jurisconsults and of relevant scholarly literature) appears as offering some moral counterweight to the stories of his trial for treason and of his rebellion that, respectively, preceded and ended this paragraph in Ibn Hajar's text. This nuanced picture, and this appreciation for at least some of Qurqumās' actions, is certainly not shared by Ibn Ḥajar's colleagues. Al-Maqrīzī (d. 1442), in his annalistic chronicle of Egyptian history up to his own final days (844 AH/1441 CE), Kitāb al-Sulūk li-Ma 'rifat Duwal al-Mulūk, added the following, very different, personal impression of immorality and divine judgement to his obituary of Qurqumās (which otherwise parallels that of Ibn Ḥajar, apart from offering some greater factual detail):

\begin{abstract}
The quality of abstinence from forbidden acts of moral defilement used to be ascribed to him (kāna yūṣaf bi-iffat 'an al-qādhūrāt al-muhrima), as well as knowledgeability, experience, horsemanship, and bravery. Eventually, however, he was corrupted (afsada amruhu) by his pride and arrogance, by his hyper-foolishness (fart raqā'atihi) and excessive self-indulgence (shiddat i 'jäbihi bi-nafsihi), and by contempt for the people (ihtiquār al-nās), exaggerated punishment (al-mubālagha fī l-uqūba), and mercilessness (qillat al-rahma). God Almighty certainly had him treated throughout his ordeal in a manner that was akin to his own actions (Allāh ta'ālā 'āmalahu fì mihnnatihi min jins a'mālihi); \{And your Lord does injustice to no one (Q18: 49) \}. ${ }^{14}$
\end{abstract}

Contrary to Ibn Ḥajar's balancing act, al-Maqrīzī’s obituary thus ends on a strong moralizing note that even appeals to Quranic rulings to explain how Qurqumās was a transgressor, and how his execution should be considered lawful and a restoration of proper, divinely ordained order. This particular discrediting conclusion of Qurqumās's obituary by al-Maqrīzì finds its equivalent in the more extensive biography and obituary of him that were produced by al-Maqrīzīs student and younger colleague, Jamāl al-Dīn Yūsuf Ibn Taghrībirdī (1411-1470). Thus, in the dynastic chronicle al-Nujūm al-Zāhira fī Mulūk Miṣr wa-l-Qāhira, Ibn Taghrībirdī ends his (otherwise factually again reproductive) obituary with the following judgmental notes:

Qurqumās was an amir [who displayed] great courage, fearlessness, and knowledgeability in the arts of horsemanship, and he has some collaborative skills - depending on the circumstances. But he also is unjust, oppressive and pompous (fìhi zulm wa-'asf wa-jabarūt). Despite his courage and fearlessness he was never very successful in combat (fí l-ḥurūb), because of the lack of coordination between his feet and his hands (li-'adam muwāfaqat rijlayhi li-yadayhi): every time he entered combat (al-harb), he stopped moving his feet to spur on his horse because of his pre-occupation with his hands - this is a grave handicap for

14 al-Maqrīzī, Sulūk (1956-1972), 4, 1150. 
a horseman, which is also known to have affected some predecessors among the horsemen of rulers [...]. [His nickname] 'Ahrām Ḍāgh' means mountain of the Pyramids; he was named like that long time ago for his arrogance and haughtiness (li-takabburihi wa-ta'äzumihi)." ${ }^{\prime}$

Just as al-Maqrīzì then, Ibn Taghrībirdī ends his obituary on a particularly moralizing and discrediting note. He assigns to Qurqumās various qualities that were considered morally reprehensible, from the unlawful conduct generally associated with the semantically very powerful notion of $z u l m$ (injustice) and its equivalents to the attitudes that, in Ibn Taghrībirdī's reading, would have gained him his infamous Turkish nickname Ahrām $\underline{D} \bar{a} g h$. Ibn Taghrībirdī's own background and interests, being the son of a leading military commander and a great fan of martial arts (including horsemanship, furūsiyya) and of practices of warfare (harb) come to the fore in his suggestion that Qurqumās lacked certain horsemanship skills. By invoking a lack of martial qualities the courtier-historian Ibn Taghrībirdī discredited Qurqumās in a manner that parallels in highly informative ways how the scholar-historian al-Maqrīzì had discredited his persona by his invocation of Quranic rulings.

The stories about Qurqumās in 15th-century Egyptian chronicles and biographical dictionaries contain dozens of factual and judgmental references of varying size and detail that display many similarities with those presented here. ${ }^{16}$

15 Ibn Taghrībirdī, Nujūm (1909-1936), 7, 257; Ibn Taghrībirdī, Nujūm (1963-1972), 15, 468. Similar statements and explanations may be found in Ibn Taghrībirdì's longer biography of Qurqumās in Manhal (1984-2009), 9, 57-63, esp. 57 (meaning of his nickname) and 62 (his arrogance; "he is unjust, oppressive and pompous" ['indahu zulm wa-'asf wa-jabarūt]; his poor horseman skills).

16 An adapted summary version of Ibn Taghrībirdī's biography was reproduced by al-Sakhāwī (ca. 1427-1497) in Daw' (2003), 6, 219-220, including similar references to his arrogance and injustice (muta'āziman mutakabbiran zāliman) and adding that "due to his arrogance, haughtiness, and lack of friendliness the common people cheered about his capture and ruin (li-takabburihi wa-ta'āzumihi wa-'adam bashāshatihi sarra l-'āmma bi-msākihi wa-tlāfihi)". Another slightly younger contemporary of Ibn Taghrībirdī, al-Jawharī (1416-1495), produced his own moralizing report, in which he introduced the story that Qurqumās' corpse "had remained lying on the ground for a long time, until it was committed to the earth, [being thus disgraced] after [having known so much] grandness and prosperity", and in which he also added the explanation that his injustice had been directed "against the common people, especially women" (zalama fì al-ra 'iya lā siyamā al-niswān) and that "he was oppressive to the urban population" (thaqula 'alá ahl al-balad). al-Jawharī, Nuzhat (1970-1994), 4, 128. According to Ibn Iyās (1448-1524) the population's dislike for Qurqumās was fed by stories such as that "it was thought that the jinn were in his service in order to reveal acts of stealing” (yuzannu anna l-jinn yakhdimūnahu fì zhār al-sariqāt). Ibn Iyās, Badā'i ' (2010), 2, 203. This connection with popular beliefs and the supernatural was first made by al-Maqrīzī, who stated that Qurqumās was approached by people "who made the ignorant believe ... that they had insight in the knowledge of the unseen" (alladhin yu- 
They all attest in various ways to that multiplicity of voices and to the quite outspoken opinions that the persona of Qurqumās evoked. Amidst this multiplicity of authorial voices, each of which brought to bear its own interests on the remembrance of Qurqumas' persona, there also appear some interesting commonalities that transcend any issues of factuality and of intertextuality. Above all, most of these contemporary narrative memories of Qurqumās - with the notable exception of Ibn Hajar's - appear to have been shaped by notions of transgression and immorality, which were used to frame his active participation in the struggle for power that followed sultan Barsbāy's demise, to explain his defeat and to legitimate his trial for treason and his execution. This particular historiographical framing of Qurqumās' career appears thus as part and parcel of the complex contemporary politics of historical truth, undergirding in this case the idea of history's culmination in Jaqmaq's victory and reign.

\section{Qurqumās and sultan Barsbāy: narrating service, reward and empowerment}

Most of the stories about Qurqumas' life and times obviously relate not to Jaqmaq's but to Barsbāy's reign. From them another remarkable multiplicity of authorial voices appears that at the same time similarly attests to the workings of these politics of historical truth, and to their meaningfulness for the changing social and political orders of the time. In the case of Qurqumas' relation with Barsbāy's reign, however, that multiplicity appears within rather than merely between particular texts. The above-mentioned assessments by al-Maqrīzì and by Ibn Taghrībirdī are indeed not outright negative, since they both also assign particular positive qualities to Qurqumās that tie in more smoothly with the commending assessments of Ibn Hajar. What the former two authors (al-Maqrīzì's statement that "he was corrupted" [afsada amruhu] most explicitly) seem to suggest is that Qurqumās' immorality was part of a historical process of transformation that eventually culminated in his trial and execution. In many ways, as part and parcel of those very same politics of historical truth, this processual framing may be understood as squaring the circle, explaining away historical inconsistencies arising from Jaqmaq's usurpation of the sultanate from Barsbāy's son and heir, and connecting stories of Qurqumās' endgame as a rebel against the legitimate

wahhimūna jahlat al-nās ... la-hum ițlā' 'alá 'ilm al-ghayb). This author continued that Qurqumās was advised by people who claimed to be masters of geomancy ( $i l m$ al-raml) and astrology ('ilm al-nujūm). al-Maqrīzī, Sulūk (1956-1972), 4, 1082-1083. 
royal authority of Jaqmaq with those of his many years of high-profile leadership, as Jaqmaq's peer, under sultan Barsbāy's equally legitimate authority.

In fact, as will be detailed below, all authors had similar stories to tell at various places in their chronicle narratives about the constructive effects of Qurqumāș' representation of Barsbāy. They all tended to do so without feeling any urge to announce or develop the demoralizing framing of their final judgements. Eventually, however, only Ibn Hajar chose to summarize and explain these stories in his hindsight obituary in the same positive light that appears as a commonality for their historiographical framing in (and during) the many years of sultan Barsbāy's reign. Breaking down these demoralizing barriers of what we might identify as post-Barsbāy truth politics, it is this far more positively framed textual relationship between Qurqumās' persona and the social and cultural contexts of Barsbāy's reign that invites for more detailed exploration.

As mentioned before, the general account of the life and career of the amir Sayf al-Dīn Qurqumās al-Sha bānī al-Ẓāhirī al-Nāṣirī Ahrām Dāgh that may be recovered from shared factual data and related intertextualities in narrative reports appears as a very traditional micro-history of military service and political empowerment in the long history of the Cairo Sultanate. The young boy Qurqumās - of unknown origins but probably born in the late 1380s somewhere in the Caucasus - had been bought on Cairo's slave markets by sultan al-Z̄āhir Barqūq at some time in the 1390s. He entered the royal service as a member of the sultan's personal retinue, the khasșakiyya, and as a member of the privileged corps of the dawādarriyya, the 'keepers of the royal inkwell', during the subsequent reigns of Barqūq's son al-Nāșir Faraj and of the usurper al-Mu'ayyad Shaykh. Only in 1421, in his thirties, when the amir Țațar ascended the throne as sultan al-Ẓāhir Țațar, did Qurqumās finally acquire some rank, status and income at the court in Cairo. Soon thereafter he was appointed by Țațar's successor, sultan al-Ashraf Barsbāy, to the more senior court position of dawādār thāni, 'second keeper of the royal inkwell', a position in which he actively engaged with the performance of royal justice. In September 1423, Qurqumās was further promoted to the highest military rank of amir mï $a$, 'commander over 100', and he was sent to Mecca with his troops, with the special mission to enhance the sultan's control over the region of the Hijāz. Almost three years later, in August 1426 - a few months after his return from his only partly successful mission in the Hijāz - he was made hạjib al-ḥujjāb, 'doorkeeper of doorkeepers', a senior position at court that made him the highest authority after the sultan in the performance of royal justice. He remained in this position for many years, during which he was also actively engaged in two military campaigns to East Anatolia. In March 1434 Qurqumās was then appointed by sultan Barsbāy to the position of his $n \bar{a}$ 'ib, 'representative' or 'governor', in Aleppo in Northern Syria, and in this capacity he got further caught up in the 
unstable and conflictual scenery of constantly shifting alliances on the sultanate's Northern frontier zone. This seriously strained Qurqumās' relationship with Barsbāy, who feared for his loyalty and suspected him of subversion. In September 1435, therefore, Qurqumās hastened back to Cairo to convince Barsbāy of the opposite, and he was subsequently relieved of his duties in Aleppo and reinstated at court, now as amìr silāh, 'swordbearer', the second highest rank in the hierarchies of the sultan's entourage. In this capacity, Qurqumās was sent to restore order in a province in the Egyptian Delta in the course of 1436. In January 1438 he was assigned by Barsbāy to lead another military campaign, with eight other senior amirs, to East Anatolia. This punitive expedition started quite successfully, but it was aborted when the news arrived from Cairo that sultan Barsbāy had died on 6 June and that, in accordance with his own instructions, he had been succeeded by his 14-year old son, al-'Azīz Yūsuf b. Barsbāy (r. June-September 1438). ${ }^{17}$

All extant contemporary reports agree on this general chronology of Qurqumās' personal history during Barsbāy's reign. This narrative of enslavement and long-haul transfer, of military training and socialization in Cairo's barracks, and of royal favor, court membership, military leadership and political integration in the sultanate's structures, may actually be reconstructed in very parallel ways for many members of Cairo's political and military elites, especially in the 15 th century. ${ }^{18}$ One of its most distinguishing features, however, was the fact that the structural appearances that shaped Qurqumās' empowerment were those of sultan Barsbāy's reign, and that for most of that reign he was simultaneously awarded a significant role in giving shape to those structural appearances. On the one hand all extant contemporary reports indeed agree on his loyal and longstanding service as a representative of Barsbāy's authority on various fronts; these narrative sources also agree on how, in exchange for this royal service, he was continuously rewarded with rank, status, and income. On the other hand, as already became apparent in the post-Barsbay material and

17 A detailed reconstruction of Qurqumās' life can be found in the 15th-century biographical dictionaries of Ibn Taghrībirdī, Manhal (1984-2009), 9, 57-62 and al-Sakhāwī, Ḍaw' (2003), 6, 197-198. Furthermore, in 15th-century Egyptian chronicles Qurqumās makes his appearance on numerous occasions in their descriptions of the events that occurred during the active years of his life. al-Maqrīzī, Sulūk (1954-1972), 4th vol.; Ibn Taghrībirdī, Nujūm (1909-1936), 6th and 7th vol.; al-Jawharī, Nuzhat (1970-1994), 3rd and 4th vol.; al-'Aynī, 'Iqd (1985-1989), 2nd vol.; Ibn Ḥajar, Inbā' (1986), 9th vol.; 'Abd al-Bāsiț, Nayl (2002), 5th vol.; Ibn Iyās, Badā’ ‘' (2010), 2nd vol. In a number of these chronicles he also received a separate entry in the obituaries: al-Maqrīzī, Sulūk (1954-1972), 4, 1149-1150; Ibn Taghrībirdī, Nujūm (1909-1936), 7, 255-259; al-Jawharī, Nuzhat (1970-1994), 4, 128-129.

18 See e.g. Loiseau 2014, 173-200; Mortel 1996; Petry 1993. 
as will be detailed further below, almost all of these particular anecdotes and comments about Qurqumās also appear as having been constructed around the grand themes of a ruler's legitimate (or illegitimate) use of symbolic and physical violence. The diverse, rich and overlapping narrative moulds that are offered by these two themes are arguably as ancient and effective as human imagination is. In their more explicit formats of, respectively, justice and warfare they have formed and informed many textual, cultural and political communities, including in Arabo-Islamic contexts. ${ }^{19}$ At the same time, on a more theoretical level, scholars from Ibn Khaldūn over Max Weber to Charles Tilly and Pierre Bourdieu have continuously joined intellectual forces to identify and clarify how these varieties of violence and coercion wielding may be used to define, explain and understand better macro-historical processes of state formation, state transformation and state deformation. ${ }^{20}$ As a result, justice and warfare appear as highly functional narrative tools that enable contemporary authors and readers and modern researchers alike to connect the many and diverse stories about Qurqumās in coherent, unifying ways to the larger picture of the formation and transformation of sultan Barsbāy's state. In the eventful micro-history of what Qurqumās did they present themselves as highly functional devices that continue to give shape to those structural appearances of sultan Barsbāy's reign. At least, this is the argument that will be developed in further detail below.

There is, however, more to this than just this particular identification of justice and warfare as the practical middle ground between the micro-history of Qurqumās' acts and the macro-history of Baybars' state. Amidst the multiplicity of contemporary authorial voices the symbolic violence of justice and the physical violence of warfare certainly also make their appearance in the format of their opposites, such as in Ibn Taghrïbirdī's aforementioned qualification of Qurqumās as "unjust, oppressive and pompous (fīhi zulm wa-'asf wa-jabarūt)" and as

19 See e.g. DARling 2013; KeAney 2013.

20 See BouRdiEU 1994, 4: "I would say, using a variation around Max Weber's famous formula, that the state is an $\mathrm{X}$ (to be determined) which successfully claims the monopoly of the legitimate use of physical and symbolic violence over a definite territory and over the totality of the corresponding population"; see also Charles Tilly's paradigm-shifting statement that "war makes states, and states make war" and his related, by now widely shared, historical definition of states as "coercion wielding organizations that are distinct from households and kinship groups and exercise clear priority in some respects over all other organizations within substantial territories" (Tilly 1992, 1; Tilly 1985) (also quoted in Steinmetz 1999, 8; Scheidel 2013, 5; Dumolyn / VAN STEENBERGEN 2017). For Ibn Khaldun's highly impactful views on the relationship between justice and political order, see BROADBRIDGE 2003; for the historiographical impact of his wellknown views on the historical, cyclical relationship between social integration, coercion wielding and state formation, see RABBAT 2012; VAN STEENBERGEN (in press). 
a failure "in combats"(fì l-ḥurūb). In this double, moralizing capacity, these two narrative devices of justice and warfare also connect larger state formation stories such as that of sultan Barsbāy or for that matter of sultan Jaqmaq to particular, contested claims of legitimate rule and to the creative construction of teleologies of historical, natural and therefore legitimate political order. How these politics of historical truth played out for Qurqumās' persona in Jaqmaq's case appeared, as demonstrated above, in pretty straightforward manners from the quite outspoken opinions that his short-lived leadership and action in the autumn of 1438 evoked. Framed as an innate transgressor's act of violent rebellion by the majority of contemporary authors, this action naturally required order and justice to be restored by military defeat, imprisonment, trial, and execution, so that the reign of Jaqmaq could be made to appear to begin as though from a cleared, purified and legitimate slate. How this played out for Qurqumās' persona during the many years of Barsbāy's case, however, appears as less straightforward to define, as more complex to pinpoint amidst that inter- and intra-textual multiplicity of voices, but certainly also as more revealing for the larger picture and structural appearances of the formation of sultan Barsbāy's state. A detailed presentation for the reign of Barsbāy of the many stories about Qurqumās and of their interpretation - not just from relational but also from moralizing semantic and discursive perspectives as framed by the devices of justice and warfare is therefore in order.

\section{Justice, Warfare, and the Messy Process of State Formation}

\section{Qurqumās and the administration of the sultan's justice}

In the above-mentioned obituary Ibn Taghrībirdī states that the first executive secretary of the second rank (dawādār thānī) "to pass judgment among the people" (hakama bayna l-nās), and to have "orderlies at his door" (nuqabä' 'alā bābihi) was Qurqumas al-Sha'bānī, in the period 1421-1422. ${ }^{21}$ This constructive role in the administration of justice seems to have continued when, in 1426, Qurqumās was made chief chamberlain (ḥajjib al-ḥujjāb), a position that is known for expanding its traditional area of jurisdiction beyond the sultan's court and the citadel's military barracks since the later 14 th century. ${ }^{22}$ Not much is said in

21 Ibn Taghrībirdī, Nujūm (1909-1936), 6, 356 and 7, 255; see also RAPOPORT 2012, 86; IRWIN 2002, 67.

22 RAPOPORT 2012, 81-84. 
any contemporary text about what it was that Qurqumās actually did during his eight-year term (August 1426-March 1434) in this office. There is, however, one more explicit reference, in al-Maqrīzì's $S u l u \bar{k}$, that appears as highly suggestive in this respect.

The year 832 (1428). The month Muharram. [...] In this month the amir Qurqumāṣ, chief chamberlain, tracked down the spaces of depravity (mawādi` al-fasād). He poured away [many barrels] of wine and burned a lot of intoxicating hashish; he tore down [any infrastructures that were constructed at] these urban spaces and he forbade [people] from gathering at the spaces of depravity (mawā di $^{`}$ al-fasād). ${ }^{23}$

In this particular case the chief chamberlain Qurqumās is remembered for assuming an active role in the preservation of the morality of urban spaces. Traditionally, this type of moral activism and these paradigmatic stories of targeting urban "spaces of depravity" (mawā involving alcohol and drugs tend to be associated with the religious invocation of "commanding right and forbidding wrong" (al-amr bi-l-ma'rüf wa-l-nahy 'an al-munkar) and with the religiously defined duties of the hisba institution and its performer, the muhtasib. This invocation is, however, also a public duty incumbent upon any Muslim, including upon Muslim rulers, and from this particular version of this well-known storyline Qurqumās therefore emerges as no less than a champion of proper Muslim behaviour. ${ }^{24}$

Later in his career, when he was sent to Aleppo to act there as the sultan's governor (nā'ib) (March 1434-October 1435), Qurqumās is also remembered for assuming a similarly active role in the local administration and maintenance of justice, and for "commanding right and forbidding wrong" in this urban center of Northern Syria more in general. In his biography of Qurqumās, Ibn Taghrībirdī in particular hints at the almost natural connection between issues of social justice and Qurqumās' actions in a short but revealing passage in his biography:

In the year 837 (1434) [...] Qurqumās headed for Aleppo and he ruled over it in his usual manner (hakamahā wa-fa'ala fìhā 'alá 'àdatihi). There too he acquired high status and much respect (qawiyat hurmatuhu aydan bihā). He introduced all kinds of new punishments for evildoers (abda'a fì l-mufsidīn bi-anwā' al-'adhāb). ${ }^{25}$

Ibn Taghrībirdī clearly suggests a direct continuity with Qurqumās' moral activism as a chief chamberlain in Cairo. In this case, however, that activism is not so

23 al-Maqrīzī, Sulūk (1956-1972), 4, 790.

24 Cook 2000.

25 Ibn Taghrībirdī, Manhal (1984-2009), 9, 58. 
much related to the organisation of urban space, but rather appears as socially defined, in his punitive interaction with the 'evildoers' among Aleppo's populations.

From these and related references Qurqumās' actions in the cities of Cairo and Aleppo appear thus explicitly as directly connected to the administration of justice and to the exemplary maintenance of urban order more in general, in different spatial and social contexts that have deviation from Islamic norms and escape from the authority's control in common. ${ }^{26}$ The afore-mentioned biographical comments by contemporary authors that cast the impression of Qurqumās' own immorality furthermore all situate his alleged vices in the context of the same active engagement with the administration of justice vis-à-vis various urban groups. Ibn Taghrībirdī's qualification of Qurqumās as having been "unjust, oppressive and pompous" ('indahu zulm wa-'asf wa-jabarūt) only acquires its full meaning in this context, ${ }^{27}$ as does al-Maqrīzī's reference to Qurqumās' "contempt for the people (ihtiquarr al-nās), exaggerated punishment (al-mubālagha $f \bar{\imath}$ l-'uqūba), and mercilessness (qillat al-rahmma)". ${ }^{28}$ Whatever their tone and purpose, these and similar comments are all equally suggestive of the close relationship between Qurqumās' actions and the administration of justice.

It has actually been argued in modern scholarship, by Robert IRWIN and Yossef RAPOPORT in particular, that some of these reports about Qurqumās al-Sha'bānī demonstrate that he was an important agent in a wider historical process of the empowerment of the ruler's authority (siyāsa) over the shari'atic authority (fiqh) of Islamic scholars and judges in the administration of justice. ${ }^{29}$ It has also been argued by Kristen STILT that in 15th-century historiographical reports the sultan's authority (siyāsa) and his agents appropriated in remarkably hegemonic ways the duties of "commanding right and forbidding wrong" and of the preservation and restoration of social order. ${ }^{30}$ The stories and judgements about Qurqumās' involvement in the administration of justice indeed all contribute to this structural appearance of the empowerment of, in this case, sultan

26 According to Ibn Taghrībirdī Qurqumās also "showed piety and virtuousness" (yuzhir al-tadayyun wa-l-iffa). He further added that "he had studied fiqh and had learned some scholarly matters” (kān yatafaqqah wa-yaḥfaz masā'il). Ibn Taghrībirdī, Manhal (1984-2009), 9, 62. In these statements he was followed by al-Sakhāwī. Al-Sakhāwī, Ḍaw' (2003), 6, 198. Also alJawharī alluded to Qurqumās' virtuous attitude as "he abstained from sodomy, wine and adultery ('afïf 'an al-lawāṭ wa-l-khamr wa-l-zinā), al-Jawharī, Nuzhat (1970-1994), 4, 129.

27 Ibn Taghrībirdī, Manhal (1984-2009), 9, 62.

28 al-Maqrīzì, Sulūk (1956-1972), 4, 1150.

29 Ibn Taghrībirdī, Nujūm (1909-1936), 6, 356 and 7, 255; see also RAPOPORT 2012, 86; IRWIN 2002, 67.

30 Stilt 2011, 204-205. 
Barsbāy and his entourage, and of their successful integration of even liminal urban spaces and groups into the orbit of the sultan's power and authority.

\section{Qurqumās and the performance of the sultan's warfare}

In the varying narrative representations of Qurqumās' persona he appears as not just deeply involved in the administration of the sultan's justice in Cairo or Aleppo. The stories that involve him and that are rendered in most detail in various texts actually concern his participation in the pursuance of warfare and in the deployment of coercive force for the sultan. As also suggested in the summary biography that was reconstructed above, throughout the 1420s and 1430s Qurqumās is in fact awarded a leading role in the descriptions of quite a few major military campaigns that targeted elites in the Hijāz and Red Sea, in the Egyptian Delta, and in Eastern Anatolia.

Representations of the differing roles that were assigned to Qurqumās in the Hijāzi and Egyptian campaigns and in the more richly referenced Anatolian campaigns all appear as part of the same coercive framework that made for the formation of sultan Barsbāy's state.

\section{The Ḥijāz and al-Buḥayra}

Between November 1423 and November 1425 Qurqumās was active in the Hijāz, sent by sultan Barsbāy to assume military and political control over Mecca, over the leading family of the Hasanid Sharifs and its local supporters, and over the flows of resources generated by commercial circulation in the Red Sea region. This was an extremely complex episode of military force and diplomacy, in which - as John Meloy has demonstrated in great detail, from a substantial variety of Meccan and Egyptian sources - the sultan's ambitions ultimately had to be accommodated to local circumstances. As Meloy shows, in Cairo-based authors' explanations of events Qurqumās was Barsbāy's main local agent, who represented the sultan's interests in Mecca in very dominant and highly centralising ways:

In their lists of rulers and offices for the year 828/1424-1425, al-'Aynī and al-Maqrīzī state that the Mamluk amir Qurqumās was the ruler (șāhib) of Mecca, listing him along with the Timurid, Qaramanid, and other such rulers.[...] From the perspective of the Mamluk hierarchy, Qurqumās was the ruler of Mecca. ${ }^{31}$

31 Meloy 2010, 120. 
Eventually, however, instead of ruling Mecca in the sultan's name, Qurqumās was forced to pursue a far more minimalist agenda of local empowerment, targeting a more direct participation for the sultan's agents in local flows of tribute and transit trade only. In this respect, Meloy followed up from earlier scholarship in bringing up a particular story that was transmitted by al-Maqrīzì. In this story a merchant, sailing on the seasonal winds between Calicut and the Red Sea region and referred to as Nākhudhā Ibrāhīm, sailed up North in the Red Sea in 1423-1424 and ended up near the port of Yanbu', in the Hijāz. "The Mamluk amir Qurqumās was in Jedda at this time”, MeLoy explains, "and according to al-Maqrīzī, he persuaded Nākhudhā Ibrāhīm to bring his cargo from Yanbu' to Jedda". ${ }^{32}$ There may certainly be some historical value in this story, for al-Maqrīzī spent considerable time in Mecca during these years, and he maintained very good contacts with a number of Meccan colleagues. For him, however, this value lay not in what it was that protagonists such as Ibrāhīm and Qurqumās actually did, but rather how that helped to make sense of, connected with and interconnected the gradual 15th-century transformation of Red Sea trade routes and networks in general (generating more important commercial roles for Jedda and its Meccan hinterland, to the detriment of Rasulid Yemen)..$^{33}$ Moreover, what mattered most here for al-Maqrīzī, as well as for others following up from him, is how this explained and linked up with a bigger picture of the negotiated expansion of Barsbāy's involvement in the political economy of the Hijaz, through the amir Qurqumās' active participation in that negotiation. As John Meloy concluded, "the installation of the Amir Qurqumās in Mecca, although it did not last long, resulted in the establishment of a Mamluk bureaucracy in Jedda and Mecca [...] to secure the revenues of Mecca and Jedda for the Sultanate [...]."34

More than a decade later, Qurqumās - at that time amìr silāh, master of weapons, and thus a high-ranking member of the sultan's court - appears in stories about one of the many punitive expeditions that throughout the period were regularly sent against locals in the Egyptian countryside.

On Saturday, the eleventh [of Rabī` I 840 / 22 September 1436], the amir Qurqumās, amīr silāh, and the amir Jānim, amīr ākhūr, headed with a group [of rank-and-file] for al-Wajh al-Baḥrī. The reason for this was that the Awlād Bakkār b. Raḥāb, with their leader 'İsā, from the people of al-Buhayra had been joined by the so-called 'Muhārib' party (al-țâ'ifa allatī yuqāl lahā muhāarib), and [that together] they were committing evil (afsadū). ${ }^{35}$

32 Meloy 2010, 76; referring to al-Maqrīzī, Sulūk (1956-1972), 4, 680-681.

33 See VAllet 2010, 640-649, 658-670; Apellániz 2009, 106-114.

34 Meloy 2003, 13; see also Wing 2014, 63-64.

35 al-Maqrīzī, Sulūk (1956-1975), 4, 998; see also al-Jawharī, Nuzhat (1970-1974), 3, 372. 
According to al-Maqrīzī and his younger colleague, the Cairene copyist and money-changer 'Alī b. Dāwūd al-Jawharī al-Șayrafī (1416-1494), this campaign in the al-Buhayra region against the apparently subversive tribal clan of the Bakkār b. Rahāb and its allies lasted for two months. It is said to have ended when Qurqumās and three other senior amirs returned to Cairo with the deposed governor of Lower Egypt and with one Muhammad b. Bakkār b. Rahāa, who "was one of the five leading shaykhs in al-Buhayra" and who had submitted to the sultan's authority. ${ }^{36}$

As has been demonstrated, especially by Jean-Claude Garcin, by this time local tribal leaders, or shaykhs, had emerged as important local power holders in most of Upper and Lower Egypt, including in the al-Buhayra region in the Western Delta. Due to the Cairo-centered urban bias of the extant narratives, not much is known about the social, economic and political dynamics of these local leaders and their tribal formations. ${ }^{37}$ In 1436 , however, local competition over resources and authority between the sultan's local representative and one of these tribal groupings had become sufficiently intense (and detrimental to the sultan's interests) to attract Cairo's interest, in the format of a punitive military campaign as well as of these haphazard reports that made it into contemporary chronicles. In their own different ways, both this campaign and these reports were clearly pursuing the restoration, or expansion, of the sultan's power and authority, among the Egyptian Delta's local elites and among Cairo's court audiences, respectively. Certainly this microhistory of Qurqumas, a handful of his peers, their troops and the Bakkār b. Rahāāb was all about making these claims.

\section{Anatolia}

Before and after his involvement in this punitive expedition to the Egyptian Delta, Qurqumās also made his appearance as a royal agent at four moments of military campaigning in Eastern Anatolia. Here he assumed a variety of roles in sieges and conquests of different strategic towns. In the spring of 1429 Qurqumās is reported to having been sent with three other senior amirs from Barsbāy's court and with 400 mamlüks to come to the assistance of the besieged Anatolian town of Harput; with Harput relieved before their arrival, Qurqumās, his fellow amirs and a handful of Syrian governors used the opportunity to move on and to take

36 al-Maqrīzì, Sulūk (1956-1975), 4, 1002; al-Jawharī, Nuzhat (1970-1974), 3, 376-377. 37 GARCIN 1974, 360-362, 441-445; GARCIN 1969, 47; see also RAPOPORT 2004, 3-5; FRANZ 2008, 136, 138-139. 
the town and citadel of al-Ruhā (Edessa) from the Aqquyunlu Turkmen; it is then explained that eventually Qurqumās was stationed by order of the sultan at the frontier fortress of al-Bīra, on the banks of the Euphrates, until the late summer of $1430 .{ }^{38} \mathrm{~A}$ few years later, in 1433, Qurqumās - at that time hājib hujjōāb, chief chamberlain at the royal court in Cairo - is mentioned as returning to the Anatolian region in the context of sultan Barsbāy's Āmid campaign. This was an enormous logistical operation in which the entire court (including a number of chroniclers) was brought to Aleppo, which culminated in a month-long siege of the Aqquyunlu-held town of Āmid by a Syro-Egyptian force led by the sultan himself, and which was followed by a negotiated and mostly symbolic settlement with the Aqquyunlu leadership, a precipitate withdrawal of the royal army to Aleppo, and then their glorious return to Cairo. ${ }^{39}$ During his term of office as n $\bar{a}$ ' $i b$ of Aleppo in the next two years (1434-1435) Qurqumās was said to have been involved - with very mixed results - in no less than three local expeditions into Eastern Anatolia, to relieve al-Ruhā from an Aqquyunlu siege (May 1434), to take the Dulgadirid town of Mar'ash (December 1434), and to take the strategic and locally highly disputed town of Kayseri (April-June 1435); most of these campaigns came to naught, mostly for reasons beyond Qurqumās' doing or control; the latter reasons also included the unexpected Anatolian empowerment, with Dulgadirid Turkmen backing, of Barsbāy's former rival for the sultanate, the amir Jānibak al-Ṣūfī (d. 1437), and when Qurqumās was allegedly implicated in this local anti-Barsbāy movement he was forced to travel back to Cairo to restore his relationship with the sultan. ${ }^{40}$ In early 1438 Qurqumās made his re-appearance in the North one last time, as the commander of another grand expeditionary force that was sent from Cairo and that included no less than eight senior amirs from Barsbāy's court and various Syrian governors; leaving Cairo in April 1438, this punitive expedition against the Aqquyunlu leadership resulted in the taking of various Anato-

38 al-Maqrīzī, Sulūk (1956-1972), 4, 803, 806-808; Ibn Tahgrībirdī, Nujūm (1909-1936), 6, 644648; al-'Aynī, 'Iqd (1985-1989), 2, 360-363; al-Jawharī, Nuzhat (1970-1994), 3, 159, 163-165.

39 al-Maqrīīi, Sulūk (1956-1972), 4, 890-898; Ibn Tahgrībirdī, Nujūm (1909-1936), 6, 691-712; Ibn Ḥajar, Inba' (1986), 8, 274-281; al-'Aynī, 'Iqd (1985-1989), 2, 428-433; see also Wing 2015, 381-383.

40 al-Maqrīzī, Sulūk (1956-1972), 4, 915-917, 937, 945-949, 958; Ibn Tahgrībirdī, Nujūm (1909-1936), 6, 718-719, 727, 732-733, 734-735; Ibn Tahgrībirdī, Manhal (1984-2009), 9, 58; Ibn Ḥajar, Inb $\bar{a}^{\prime}$ (1986), 9, 51-52; al-Jawharī's account is a close copy of al-Maqrīzī.; al-Jawharī, Nuzhat (1970-1994), 3, 286-287, 310, 316-321, 331. The essence of this story is that the sultan, suspecting Qurqumās of rebelling against him, sent a courier to summon him to Cairo; Qurqumās' swift arrival then seemed to Barsbāy proof enough for his loyalty. On the whereabouts of Jānibak alȘūfī during this period and his complex role as power broker in frontier Anatolia, see ADRIAENSSENS / VAN STEENBERGEN 2016. 
lian strongholds (Çemişgezek, Arapkir, Akşehir) and in the successful siege of the town of Erzincan; the campaign was aborted when the arrival of the news of the sultan's death in June 1438 incited Qurqumās and his colleagues to swiftly return to Cairo to secure their positions in the succession arrangement. ${ }^{41}$

In these four particular moments of military campaigning in Eastern Anatolia, in 1429, 1433, 1434-1435, and in 1438, Qurqumās' microhistory again intersects with that of the formation of Barsbāy's state in the 1430s in interesting ways. The diachronical perspective of these cases allows it even to do so in more revealing ways than his engagements with the Hijaz and al-Buhayra did. In the first two cases Qurqumās is portrayed as just one among various more and less visible military agents who were led by the sultan's Syrian $n \bar{a}$ 'ibs and by Barsbāy himself. In the latter two cases, however, Qurqumās appears as having transformed into the lead character of military action, commissioned by the sultan to militarily represent his interests in the North. Isolated in this manner from their larger contexts this series of campaigns and Qurqumās' changing role in them appear first and foremost as part and parcel of the narrative of Qurqumās' steady rise to power and to pre-eminence in Barsbāy's shadow. Nevertheless, the actual renderings of the stories that inform this narrative do not really provide much detail of what Qurqumās actually did in terms of military action and leadership to earn him his good reputation, at least not beyond his loyal service to Barsbāy. Clearly, it again was not so much the detail of these campaigns or of Qurqumās' (or anyone else's) active role in them that mattered most to those for whom these stories were meaningful, but rather the way in which they connected and contributed to a bigger picture. In this case, that bigger picture obviously again was that of the royal service of Qurqumās and his peers. It is, amongst others, this image of loyal military service to sultan Barsbāy that connects these four different moments in Qurqumās' life with each other and that, simultaneously, makes them informative and meaningful as part and parcel of another, larger narrative of the expansion of Barsbāy's state in the 1430s.

In the sultanate's North, that expansion was mainly shaped by a much longer series of military and diplomatic campaigns that were regularly organized from Syria and from Egypt throughout the 1420s and 1430s. These Anatolian campaigns were aimed in particular at the more direct integration of powerful local Turkmen leaderships into the sultan's power and authority, often in indirect competition with other transregional powers on the rise, such as the Ottomans in the West

41 al-Maqrīzī, Sulūk (1956-1972), 4, 1030, 1036, 1047, 1058-1059, 1071-1072; Ibn Tahgrībirdī, Nujūm (1909-1936), 6, 757, 759 and 7, 10; al-Jawharī, Nuzhat (1970-1994), 3, 426-427. See also Woods 1999, 67-68; DARRAG 1961, 398-399. 
and the Timurids in the East. The local leaderships of Eastern Anatolia consisted mainly of competing groups of Turkmen families and tribal formations, which dominated in diverse, constantly changing, and often overlapping ways pastures and migration routes as well as towns, urban centers, their agricultural hinterlands and the commercial routes that connected them. The most high-profile groups among these local leaderships included the Ramaḍānids of Tarsūs and Adana, the Karamānids of Konya and the Dulgadirids of Elbistan and Mar'ash. More to the East, in the Diyār Bakr-Armenia territories, the more peripatetic leadership of 'Uthmān Beg Qarā Yülük (d. 1435), his sons and grandsons, and their Aqquyunlu followers appeared for many decades as equally dominant in local power arrangements. The engagements of Barsbāy and his agents with these Anatolian arrangements concerning leadership hierarchies and access to resources occurred in a continuous mixture of diplomatic exchanges supported by threats of violence and actual military confrontations. Three of the four moments of military campaigning mentioned above, against Aqquyunlu control over Edessa (alRuha) in 1429, against the center of Aqquyunlu power in Ämid in 1433, and against the sons and successors of Qarā 'Uthmān and their control over various towns and routes in 1438, are actually reckoned among the major Anatolian expeditions of Barsbāy's reign. The outcomes of these engagements have been estimated as mixed, yielding debatable returns on huge investments of men and resources for Barsbāy, and necessitating the accommodation of the sultan's high ambitions to complex local and regional circumstances. ${ }^{42}$

\section{Qurqumās and the messy process of state formation}

State making is a messy business, in which ambitions, opportunities, resources, dependencies and extremely high stakes make for all but smooth, premeditated or linear outcomes of intense interactions. State making also is a violent business, in which the establishment and maintenance of political order always comes at a price for all those involved in the interactions. This was no different for the formation of Barsbāy's state in the 1420s and 1430s. By way of concluding reflection of this part it may well be argued that from this particular reading of extant renderings of stories such as those about Qurqumās more can, and perhaps should, be said about the messiness that also made for the formation of Barsbāy's state, and for the wider contexts of its structural appearances across the 1420s and 1430s.

42 See Darrag 1961, 363-402; Wing 2015; Woods 1999; Binbas 2016; Adriaenssens / VAn STEENBERGEN 2016. 
As John Woods in his seminal study of 15th-century Turkmen politics already suggested many years ago, throughout those two decades and the reign of Barsbāy the Hijāz and Eastern Anatolia were in many ways connected as frontier zones that were similarly targeted by the ambitious political and economic polities that were emanating from the sultan's court in Cairo, and that met with all kinds of local and regional reactions, in the Hijāz as well as in Eastern Anatolia. ${ }^{43}$ These interconnected frontier zones have so far been the subject of some scholarship, but much more work remains to be done. ${ }^{44}$ Above all, in the present context this frontier nature of the Hijāz and Eastern Anatolia, and the shared but, indeed, messy patterns of competition and accommodation that this frontier nature entailed, is certainly one alternative way in which narratives of Qurqumās' actions and experiences in both areas may be meaningfully connected. In fact, even geographically far less peripheral zones of Qurqumās' actions and experiences may be connected to these same patterns of competition and accommodation. In the city of Cairo throughout the 1420s and 1430s, in Aleppo in 1434-1435, and in the al-Buhayra region in the Egyptian Delta in 1436 Qurqumās is indeed presented as engaging in similar actions of symbolic and physical violence, even when these actions also appear as far removed from happening at any kind of territorial frontier. A useful point to reiterate in this respect, however, is the observation that Qurqumās is always portrayed as acting in the sultan's name, as being instructed by the sultan, and thus as a royal agent for sultan Barsbāy and his expanding claims to power and authority. This means that Qurqumās is presented as wielding the sultan's symbolic and physical violence in the streets of Cairo and Aleppo and with the shaykhs of the Delta in similar ways as he did with respect to the amirs of the Hijāz, the Turkmen chiefs of Anatolia and even Indian captains sailing up the Red Sea. Wherever he was made to be active, he is above all presented as successfully accommodating the sultan's ambitions to

43 Woods 1999, 50: “... these frontier skirmishes may be considered local manifestations of the larger conflict between al-Ashraf Barsbay and [the Timurid ruler] Shahrukh [r. 1405-56] over Indian Ocean-Mediterranean trade through the Red Sea and the political status of the Holy Cities of the Hijaz, the ramifications of which affected the economic, political and ideological life of the central Islamic lands until the rise of the Ottomans and Safavids at the beginning of the sixteenth/tenth century."

44 For Anatolia, see: Woods 1999, 50-54, 64-66; WIng 2007, 83, 86-87; WIng 2015, 379-380. For the Hijaz, see Meloy 2010, 113-139, Mortel 1995, 2-3; Wing 2014, 62-67; DekKICHE 2014-2015, 256-258, 263-264, 267. Another frontier zone that may be added is Cyprus and the Eastern Mediterranean. See Coureas 2013, 354-355; EdBury 2000, 141-179; APELLÁNiz 2009, 145-167. The joint consideration of these frontier zones from the connecting perspective of the politics of Barsbāy's sultanate remains limited to the by now quite outdated but yet empirically still useful study of DARRAG. 
local realities, which were always in flux and therefore shared a kind of marginality at the fringes of the reach of the sultan's violence. Rather than consisting of territorial frontiers only, those local realities represent some of the dynamic limits of the reach of Barsbāy's state and some of the social frontier zones of his order.

In view of this observation, it may then be suggested that Qurqumās is portrayed as one of the foremost mediators of the coercive strategies that were deployed to structure messy power relationships across Egypt, Syria, the Hijāz and East Anatolia into particular and flexible moulds that generated sufficient levels of political integration and hierarchical coherence to make for a state in the social reality of things. Barsbāy's state in formation appears here as a relational product, even a particular type of social network, that was continuously created and recreated as relational construct and as patrimonial apparatus by the sultan and his household, by his court and all kinds of agents and institutions that represented the court's interests, and by all kinds of local partners, opponents and subjects acting and reacting in their own best interests and according to their own political and other beliefs. In the case of Barsbāy's state, there obviously were many different kinds of local partners, opponents and subjects, and some were deeply integrated in the sultan's networks (and may even have been created by them, as with Qurqumās), some were not, and some were only halfheartedly. The latter category certainly included Egyptian shaykhs and Ḥijāzī amīrs, urban mufsidūn and Turkmen tribal groups.

\section{History, Truth and the Sultan's Order of Justice and Sovereignty}

Contemporary authors writing about the successes and failures of that messy process of state formation and transformation made for yet another type of its partners, opponents and subjects. Their narrative strategies and story telling were similarly deployed to engage in this process, and especially to structure messy power relationships across Egypt, Syria, East-Anatolia and the Hijāz in the practical and discursive realities of writing, reading, talking and thinking about them. The multiplicity of voices that arose around - and reproduced - the memory of Qurqumās' debated reputation as a royal agent in matters of justice and warfare should therefore also be considered and understood, as suggested before, as a function and a token of those strategies, and of their active participation in the era's politics of historical truth. In fact, as will be detailed below, in this capacity the many renderings of stories by these historiographical voices inform not just about the complex social contexts of the structural appearances 
that connected micro-histories such as that of Qurqumās to the macro-history of the formation of Barsbāy's state. They also have a lot to say about how those structural appearances and their structuration of socio-political messiness were qualified and imagined in meaningful ways by contemporaries, and thus also about how that imagination of royal power and of the sultan's state informed, deformed or simply structured contemporary narratives.

\section{Qurqumās and the sultan's order of justice}

As explained before, there are quite a few references that connect Qurqumās' actions during Barsbāy's reign explicitly to the administration of royal justice and to the maintenance of urban order more in general. Whatever the purposes and level of detail of these comments and observations, they actually all acquire their moralizing power first and foremost by engaging with a particular language and a particular discursive imagination of the sultan's order of justice. An insightful example of this feature is Ibn Taghrībirdī's explanation that in Aleppo Qurqumās "introduced all kinds of new punishments for evildoers (abda'a fì l-mufsidin bi-anwā' al-'adhāb)". ${ }^{45}$ This appears as a very powerful and suggestive statement by its use of the morally highly charged mufsidin (evildoers, corrupters), which is morphologically, semantically and, as part of Quranic speech, directly related to the corruption and depravity of al-fasād that al-Maqrīzì evoked when he referred to Qurqumās' actions in 1428 against "spaces of depravity" (mawā al-fasād) in Cairo. ${ }^{46}$ Together with the more general framing of Qurqumās' rulership practice in Aleppo as "usual" ('alá 'âdatihi) and as in line with his earlier actions in Cairo, Ibn Taghrībirdī creates here around Qurqumās and his engagements with justice an aura of moral continuity and of expanding restoration of a corrupted social order that connects this fragment with al-Maqrīzì's. Ibn Taghrỉbirdī's further statement in the same biography that Qurqumās "performed [the duty of] forbidding wrong” (al-qiyām fì l-nahy 'an al-munkarāt) similarly links up with al-Maqrīzī's more explicit identification of such wrongs when he explained that in 1428 Qurqumās "poured away [many barrels] of wine and burned a lot of intoxicating hashish. ${ }^{47}$ Both remind directly of the afore-mentioned religio-legal duty of "commanding right and forbidding wrong" (al-amr bi-l-ma'rūf wa-l-nahy 'an al-munkar) more in general. From these handful of references that connect

45 Ibn Taghrībirdī, Manhal (1984-2009), 9, 58.

46 al-Maqrīzì, Sulūk (1956-1972), 4, 790; see also Denny 439-440.

47 Ibn Taghrībirdī, Manhal (1984-2009), 9, 62; al-Maqrīzì, Sulūk (1956-1972), 4, 790. 
Qurqumās' actions explicitly to the administration of justice and to the maintenance of social order more in general, he definitely appears as moving on moral high ground in these authors' imaginations, at least as far as these particular text fragments are concerned. ${ }^{48}$

The afore-mentioned comments by these same authors that cast the exact opposite impression all share with the latter appreciative references the operationalisation of an equally powerful and semantically charged language to blame him for overstepping his limits in performing that administration. Ibn Taghrībirdī's qualification of Qurqumās as having been "unjust, oppressive and pompous" ('indahu zulm wa-'asf wa-jabarūt) aligns with this argument, ${ }^{49}$ as does al-Maqrīzī's reference to Qurqumās' “contempt for the people (iḥtiqār al-nās), exaggerated punishment (al-mubālagha fì l-'uqūba), and mercilessness

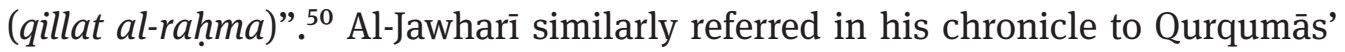
oppressive actions by way of the semantics of justice when he claimed that "he had treated the common people, especially women, with injustice" (zalama fi al-ra iya lä siyamā al-niswān) and that "he was oppressive to the urban population" (thaqula 'alá ahl al-balad). ${ }^{51}$ These are the semantics of justice -or of its absence, as invoked by the uses of fasād, munkar, zulm and their variants - that connect these opposite value judgements across this multiplicity of intra-textual voices, and that also connect them to Ibn Hajar's more consistent approving statements about Qurqumās' consultation of jurisconsults (fuqaha ') and books of religious knowledge ( $k u t u b$ al-'ilm).

Whatever their tone and purpose, these references are all equally suggestive of the close relationship between Qurqumās' actions and the morality of royal justice. The fact that in these differing judgements of the moral value of Qurqumās' legal actions, and of the legitimacy of reactions to them, all authors equally insisted on his role in the administration of royal justice confirms above all that this relationship was considered to be not just real and morally charged, but also extremely meaningful for all. This generally shared appreciation of the centrality of justice as a signifier for Qurqumās' persona easily compensates for the relatively limited amount of reports that make any more concrete statements

\footnotetext{
48 See also Ibn Taghrībirdī's comment that Qurqumās also "showed piety and virtuousness" (yuzhir al-taḍayyun wa-l-'iffa). Ibn Taghrībirdī, Manhal (1984-2009), 9, 62. al-Sakhāwī, Daw' (2003), 6, 198. Al-Jawharì's claim that "he abstained from sodomy, wine and adultery" ('afif 'an al-lawāt wa-l-khamr wa-l-zinā) is similarly meaningful in this context; al-Jawharī, Nuzhat (1970-1994), 4, 129.

49 Ibn Taghrībirdī, Manhal (1984-2009), 9, 62.

50 al-Maqrīzī, Sulūk (1956-1972), 4, 1150.

51 al-Jawharī, Nuzhat (1970-1994), 4, 128.
} 
about what he actually would have done in this context in Cairo or Aleppo. It obviously was the bigger picture that mattered most here, and that accounted for the meaningfulness of these value judgements. As part and parcel of Barsbāy's entourage Qurqumās' particular micro-history in this respect is certainly one of the practical administration of the sultan's justice. The messy detail of that practical administration may not have been particularly highly valued, but as a constitutive factor for the discursive construction of Barsbāy's state as upholding the sultan's order of justice Qurqumās' micro-history and the general effect of his actions as dawādār, hâajib al-hujjāb and $n \bar{a} \mathfrak{\prime} i b$, appeared as highly valuable. At least, its historiographical framing as part and parcel of a natural, coherent and just historical process that involved the widening expansion of the administration of royal justice and the restoration of social order across the Syro-Egyptian realms was considered extremely functional for as long as the timeframe's hegemonic discourse was that of Barsbāy's state.

\section{Qurqumās and the sultan's order of sovereignty}

As in the justice context, also in the case of the story about the military expedition by a limited body of horsemen (tajrìda) to al-Buhayra a particular framing of the necessary and legitimate restoration of a social order that had been 'corrupted' is suggested by al-Maqrīzī's explicit use of the Quranic phrase afsadū ("they were committing evil", "they were causing corruption"). ${ }^{52}$ The idea of this sultanic order as a dynamic normative framework that is acted upon by various agents is not just suggested by the notion of its potential 'corruption'. It is also implied in explicit references to its restoration, as in al-Maqrīzì's closing phrase that one of the al-Buhayra shaykhs was brought to Cairo by Qurqumās and his fellows after he, literally, "had entered into the [sultan's] obedience” (qad dakhala fì l-țā'a), or in al-Jawharì's rendering of this same act of submission as "he had come [to the sultan's court] in obedience" (qad hadara ță'i $\left.i^{\prime} a n\right) .{ }^{53}$ In their own discursive ways, these reports were clearly pursuing the establishment, or restoration, of the sultan's proper political order, in that order's reproduction in Cairo's hegemonic historical discourse in particular. This idea of the sultan's order as the proper one is also implied in al-Maqrīzī's and al-Jawharī's shared use of the semantics of $\operatorname{ta}^{\mathrm{c}} a$ ('obedience'), which actually is fasād's ('corruption') Quranic counterpart and

52 al-Maqrīzì, Sulūk (1956-1975), 4, 998; see also al-Jawharī, Nuzhat (1970-1974), 3, 372. Quranic verses with this particular phrase are 27: 35, 2: 28 and 206, 7: 86 and 16: 89.

53 al-Maqrīzī, Sulūk (1956-1975), 4, 1002; al-Jawharī, Nuzhat (1970-1974), 3, 376-377. 
which is intricately tied up with wider concepts of divinely ordained authority and coercive power. ${ }^{54}$

Most, if not all, relevant historiographical narratives informing about Qurqumās' Anatolian adventures concern similar renderings of stories about military expeditions of horsemen (tajrīda) that are again framed against the discursive background of a sultanic order established through relationships of obedience $\left(t \bar{a}^{c} a\right)$. In these cases too, this order is presented as operating as a dynamic normative framework that is acted upon by various agents, who were either "moving out of obedience” (kharaja 'an al-țā'a), "aspiring for obedience” (raghiba fì l-țā'a) or "entering into obedience [to the sultan]" (dakhala fi țā'atihi)..$^{55}$ The integrative nature of this framework and its practical link with the structural appearances of Barsbāy's state are suggested most forcefully by al-Maqrīzì. He explains how the conquest of Erzincan in 1438 was a very negotiated matter, which involved no actual use of violence, but rather an exchange of embassies and precious gifts, followed by the appointment of one member of the Aqquyunlu leadership in "the sultanate's governorship in Erzincan” (niyābat al-salțana bi-Arzinkān), the public "swearing of an oath by the people of Erzincan to uphold their obedience to the sultan" (halafa ahl Arzinkān bi-l-iqāma 'alā țā'at al-sulțān), and the opening of the city's gates for the army to enter "without causing any harm or plunder" ( $\mathrm{min}$ ghayr darar wa-lā nahab). ${ }^{56}$ This safe and sovereign order and its relationship with the structural appearances of Barsbāy's state is qualified in further symbolic and also practical detail in historiographical narratives about the Amid campaign of 1433. The engagements between the two parties - the sultan and Qarā Yülük, as the in- and outsiders of this order respectively - appear here in far more violent formats, such as raiding parties, direct combats, siege warfare and public executions. Their resolution, however, is explained by al-Maqrīzī as again involving an exchange of embassies and gifts that resulted in "the conclusion of a settlement with [Qarā Yülük] and his commitment by oath to obedience [to the sultan]" (hattā 'aqada l-ṣulh ma'ahu wa-ḥallafahu 'alā l-țā'a). ${ }^{57}$ The meaning of this arrangement is then further qualified by al-Maqrīzī in both symbolic and practical terms:

54 Blankinship 2003, 3, 566-569.

55 al-Maqrīzì, Sulūk (1956-1972), 4, 806, 896, 948 and 1058; Ibn Tahgrībirdī, Nujūm (1909-1936), 6, 644, 645 and 706; al-'Aynī, 'Iqd (1985-1989), 2, 432.

56 al-Maqrīzì, Sulūk (1956-1972), 4, 1059; also with less explicit detail in Ibn Tahgrībirdì, Nujūm (1909-1936), 6, 759.

57 al-Maqrīzì, Sulūk (1956-1972), 4, 896. Also similar wording in al-'Aynī, 'Iqd (1985-1989), 2, 432; Ibn Tahgrībirdī, Nujūm (1909-1936), 6, 705. 
The settlement (al-ṣulh) that was agreed upon was the following: Qarā Yülük will not interfere with anything concerning the realm's peripheries (ațrāf al-mamlaka), from al-Rahba to Divriği; he will facilitate passage for pilgrims, merchants, and other travellers; he will not interfere with Ḥișn Kayfā, nor with its people and [Ayyubid] overlords, nor with Dawlāt Shāh, the lord of Egil and its citadels; he will strike coins (sikka) and have the Friday prayer (khutba) in Diyār Bakr delivered in the name of the sultan; he will execute the sultan's orders (marāsìm al-sulțān) that are directed to him. ${ }^{58}$

Most contemporary reports actually reiterate these same particular practical and symbolic aspects of safety and sovereignty that were claimed to make for the sultan's order and for the North's integration into it. ${ }^{59}$ By constructing and explaining in these ways power relationships between, especially, the sultan and various Turkmen leaderships of east Anatolia, all kinds of connections are woven - also semantically - by these contemporary authors that arguably communicate first and foremost a coherent narrative of successful expansion of, and state formation around, the sultan's sovereignty over a hierarchy of 'obedient' subjects. Al-Maqrīzi formulates the workings of this abstract order of sovereignty most explicitly and most forcefully when he concludes his narrative about the campaign of 1438 with an incisive personal reflection on the remarkable success of that political order, again typically embedded in highly suggestive Quranic discourse:

How remarkable is it that the town and citadel of Akşehir and the town of Erzincan were taken for, and in the name of, sultan al-Malik al-Ashraf Barsbāy while he was dead. [How remarkable is it that] he stirred authority and awe in the hearts of the people of these towns (sațwatuhu wa-muhābatuhu fĩ qulūb ahl tilka l-bilād) despite their distance from him, and that his commands were effective among these populations (awāmiruhu nāfidha tī tilka l-ra' $\bar{a} y \bar{a})$. If they would have known that he had died, the sultanic army would not have been able to do anything like that. But $<<$ God does that He desires $>>$ (allāh yaf'al mā yurìd); $<<$ Whensoever God desires evil for a people, there is no turning it back >> (idhā llāh arāda bi-qawm sū'an fa-lā maradda lahu). ${ }^{60}$

The authors of these narratives about military campaigning in Anatolia thus presented stories about local actions in ways that ascribed to a particular imagination of the sultanate's Northern expansion, as part of a natural, even divinely ordained, process of integrating outsiders, disciplining disorder, and establishing the sultan's sovereign order. Interestingly, however, these same authors occa-

58 al-Maqrīzī, Sulūk (1956-1972), 4, 897.

59 Ibn Tahgrībirdī, Nujūm (1909-1936), 6, 705; Ibn Ḥajar, Inbā' (1986), 8, 281; al-'Aynī, 'Iqd (1985-1989), 2, 432. See also Wing 2015.

60 al-Maqrīzì, Sulūk (1956-1972), 4, 1071-1072. Quoting from Quran 22: 14, and 13: 11 (Translation from ARBERRY 1955). 
sionally also framed such stories and actions as counterproductive for that imagination. Some of the narratives of the first Anatolian campaign that involved the participation of the amir Qurqumās, in 1429, included detailed descriptions of the atrocities committed against the population of al-Ruhā/Edessa by the sultan's mamlūks. Whereas Ibn Hajar restricted himself in his summary of the campaign to the statement that "they committed atrocities" (afhashū), al-'Aynī chose to explain in a moralizing tone that their behaviour was "worse than what unbelievers (kuffār) would do."61 Al-Maqrīzī, and Ibn Taghrībirdī after him, communicated most frankly and most critically about the nature of, and responsibility for this course of events. In fact, they both very tellingly equalled the sack of the town of Edessa with, as al-Maqrīzì phrased it, "the way the companions of Tīmūr acted when they took the towns of Syria" (ka-fi'l aṣhāb Tìmūr lammā akhadhū bilād al-Shām). ${ }^{62}$ Al-Maqrīzī even added another personal closing statement in which he held al-Ashraf Barsbāy morally responsible for his troops' bad behaviour; Ibn Taghrībirdī in his turn chose to quote this statement verbatim, but he added a very apologetic explanation to his teacher's observations:

Thus ended al-Maqrīzì's speech. I said (qultu): what that rabble did did not happen due to the sultan's volition, nor by his command, nor during his presence; it has already been explained that the Syrian governors and the leading amirs forbade them to enter the citadel [of Edessa] altogether, but they were unable to enforce that due to the great number of Turkmen and Arabs that had joined the army for plundering, as is the tradition with armies. If al-Ashraf is responsible for sending the army towards Edessa, then this is a kind of command that any king of old and recent times should be blamed for [...]. ${ }^{63}$

Al-Maqrīzī's and Ibn Taghrībirdī's narratives of the second Anatolian campaign that involved the participation of the amir Qurqumās, in 1433, culminated in similarly engaged and moralizing statements. In his final personal reflections on the outcomes of the sultan's Amid campaign al-Maqrīzì actually claimed that "it had been a difficult journey that had done a lot of damage and that had brought no benefit" ( $k$ ānat safrat mashaqqa zā'idat al-darr 'adìmat al-naf'), that huge amounts of resources had been squandered on it, and that in fact "no one achieved anything nor did dissension cease" (lam yablugh ahad gharadan min

61 Ibn Ḥajar, Inbā' (1986), 8, 173; al- 'Aynī, 'Iqd (1985-1989), 2, 362-363.

62 al-Maqrīzì, Sulūk (1956-1972), 4, 807; also Ibn Tahgrībirdī, Nujūm (1909-1936), 6, 647 (“they did in the town of al-Ruha what Timurlank had done, and even excelled him in killing, capturing, burning, and violating women").

63 Ibn Tahgrībirdī, Nujūm (1909-1936), 6, 648; referring to al-Maqrīzī, Sulūk (1956-1972), 4, 808-809. 
al-aghrād wa-lä sakanat fitna). ${ }^{64}$ This frank concluding assessment of the Amid campaign is again repeated and rationalised in the sultan's favour - as in the case of the Edessa campaign - by Ibn Taghrībirdi.${ }^{65}$ However, the latter author was with the sultan throughout the whole journey and in the very detailed narrative that preceded his own concluding, rationalising reflections Ibn Taghrībirdī chose not to spare his reader his master's manifest shortcomings. Ibn Taghrībirdī's criticism focuses above all on his own frustrating experiences with how the logistics of the withdrawal from Amid were extremely badly handled by the sultan. He actually exemplifies the chaos which this lack of sultanic leadership created by making explicit reference to stories about the fate of the amir Qurqumās. In Ibn Taghrībirdī's narrative Qurqumās made his appearance in the sultan's entourage in the course of the precipitate and disorderly withdrawal of the armies. According to Ibn Taghrībirdī he actually was "one of those who did not know where their regiments had gone" and who had nothing better to do than to "set up shelter and hide in its shadow against the sun, because his regiment with all his mamlüks and baggage had left [from Amid] along a [different] route and it was impossible to tell when they would come back to him." ${ }^{66}$ For Ibn Taghrībirdì this one example actually demonstrated the temporary collapse of the sultan's order as "there were many more soldiers and amirs like him" so that, in the end, the sultan himself was no better off, ${ }^{67}$ and they all escaped unharmed only due to their opponents' “impotence, cowardice, and weakness". ${ }^{68}$

64 al-Maqrīzī, Sulūk (1956-1972), 4, 898.

65 Ibn Tahgrībirdī, Nujūm (1909-1936), 6, 712: ("it was a journey of great damage and little benefit" (kānat safra kathïrat al-ḍarar qalīlat al-naf') during which "no one achieved anything nor did dissension cease nor was safety established nor was the enemy repelled" (wa-lam yanal ahad fì hādhihi l-safra gharaḍan min al-aghrạ̣̄ wa-lā sakanat fitna wa-lā qāmat hurma wa-lā rtada'a 'aduww); nevertheless, "warfare has its ups and downs: one day you win, another you loose; sometimes you are lucky, sometimes you are not” (...)

66 Ibn Tahgrībirdī, Nujūm (1909-1936), 6, 708.

67 Ibn Taghrībirdī, Nujūm (1909-1936), 6, 708: "When al-Malik al-Ashraf himself became aware of his armies' limited size and of how only a small group had remained with him, that worried [the sultan] and made him fear that Qarā Yülük would attack him during the night. But there was no escape from staying at this place, due to the shattering of his armies."

68 Ibn Tahgrībirdī, Nujūm (1909-1936), 6, 708-709: "I [=Ibn Taghrībirdī] would say (qultu): during that night [after the disordered withdrawal] I began to understand the true nature of Qarā Yuluk's situation [...] The reason for this is the following: the settlement that had been concluded between him and the sultan al-Ashraf meant nothing at all (kallā shay') ... and he knew all about the shattering and dispersal that had befallen our army and about the situation that we were in, due to the short distance between us; the only reason why he forsook to attack us is impotence, cowardice, and weakness. [This is also true for] those who were in Amid.” 
This vivid and frank assessment of the Amid campaign as a military and political disaster has been extremely successful in shaping its historiographical remembrance, including into the modern era ${ }^{69}$ Nevertheless, even the most critical parts of al-Maqrīzì's and Ibn Taghrïbirdì's narratives continue to be embedded within a particular discourse of how sultan Barsbāy should or could have acted and, therefore, of the normativity and transcendent necessity of the sultan's order of sovereignty. ${ }^{70}$ Thus, in Ibn Taghribirdī's reconstruction of the negotiation between the Aqquyunlu leader Qarā Yülük and the sultan's envoy, he made Qarā Yülük exclaim almost sarcastically, but also submissively, that "by God, if the sultan had only given me half of what he spent on the shoes of his horses and of the horses of his armies, I would have submitted and entered into obedience to him [at no further expense or military pressure]". (Wa-llāh law a țānì l-sulțān nișf mā dhahaba min al-kalaf fī na'l khuyūlihi wa-khuyūl 'asākirihi la-raḍatu wa-dakhaltu fì țā'atihi.) ${ }^{71}$ Other contemporary authors, such as al-'Aynī and Ibn Ḥajar, who had also participated in parts of the campaign, embedded their entirely descriptive narratives in this same discourse of sovereign order, but they chose to do so by assuming a different position, ironing out or ignoring any messiness. ${ }^{72}$ In this respect, al-'Aynī equally presented in some detail the armies' return from Amid to Egypt, but in his narrative this appears as a smooth and glorious journey, celebrating along the way the sultan's victories and the successful restoration of his order of obedience and safety, and thus of his sovereignty. ${ }^{73}$

\section{Qurqumās and the just and sovereign order of the state}

All of these diverse renderings of stories involving the performance of the sultan's warfare appear here as not just connected through, and structured by, the mediation of social actors such as the amir Qurqumās. They also appear across these

69 al-Jawharī, Nuzhat (1970-1994), 3, 265-266; Iyās, Badā' '` (2010), 2, 150 and 152; WiET 1960, 1054; DARRAG 1961, 380 (“le fiasco de l'expédition”); Woods 1999, 52-53; Wing 2015, 386.

70 See their shared references to fitna (disorder, dissension) that was supposed to be 'silenced' by this campaign (al-Maqrīzī, Sulūk (1956-1972), 4, 898; Ibn Tahgrībirdī, Nujūm (1909-1936), 6, 712).

71 Ibn Tahgrībirdī, Nujūm (1909-1936), 6, 706.

72 There are no specific comments of this kind by these authors: not in al- 'Aynī, 'Iqd (1985-1989) nor in Ibn Hajar, Inbā' (1986) (although the latter's use of the aforementioned word fasād ['corruption'] for the damage done by the Egyptian army to agricultural production in Syria (8, 275: fasād kabīr) and around Amid (8, 281: afsadūhā) may arguably similarly be read as condemning the behaviour of the sultan's army, and thus the sultan's lack of control and leadership).

73 al-'Aynī, 'Iqd (1985-1989), 2, 432-433. 
narratives as connected and structured on the level of the meanings that were awarded to them. This happened in the format of historiographical voices' shared uses of the semantics of key signifiers of social order, such as $t \bar{a}$ ' $a$ ('obedience') and fasād ('corruption'). It also happened in the related, but diverse, narrative engagements with the idea of the sultan's order as a dynamic normative framework of sovereignty that is acted upon by various agents, from al-Buhayra shaykhs in Egypt to various local leaders in the North, and including the sultan's own military connecting them all. One of those military whose persona was made to not just socially, but also meaningfully interconnect those narratives and semantics, and to signal the expanding dynamics of that order as a function of the sultan's sovereignty, certainly was the amir Qurqumās. At the same time, across the same texts, his persona's constructive engagements with justice and social order contributed, as mentioned above, to the production of an increasingly coherent, unitary and just appearance for that acclaimed sovereignty, across the 1420s and 1430s and from Cairo to Aleppo. In other words, through stories such as those about Qurqumās the sultan's sovereign order is qualified not just as a necessary, safe and obedient one, but also as a just and even divinely ordained one. The returning explicit relationship with various structural appearances of Barsbāy's state, from the offices that Qurqumās performed to the honours that were exchanged with Anatolian chiefs, presents the dynamic establishment of this order in the format of a coherent narrative of successful expansion of, and state formation around, the sultan's sovereignty and justice over a hierarchy of 'obedient' subjects. Participating in this way in the era's politics of historical truth, this kind of presentation ascribes to a very particular and widely shared - even though not necessarily widely accepted - discursive imagination of the expansion of Barsbāy's state, as part of a natural, even divinely ordained, process of integrating outsiders, disciplining disorder and corruption and establishing the sultan's sovereign and just order.

\section{Concluding Observations}

At the end of this article, it may be concluded that more questions may have been raised than answered by enlarging and complicating the range of readings of extant narratives in the microscopic social and cultural ways that have been attempted here. The remarkable change of fate of Qurqumās' persona before and after Barsbāy's death reminds us of how contemporary narratives and their varying renderings of stories can, and should, be looked at especially for how they enabled the accommodation of social, cultural and political change. They 
did so not just as signs and qualifiers of that history of change, but also as actors taking up differing positions in dynamic fields of relationships of power that also included their authors and audiences. Simultaneously, they often also did so as agents of powerful discourses of continuity, restoration and that same change's negation.

This detailed study of Qurqumās' case therefore certainly invites wider and deeper engagements with the intricacies of these 15th-century historiographical communities of historians, narrative texts, stories, audiences and relational and discursive politics. This may be pursued further from the perspective of reading contemporary texts as operating on a narrative middle-ground that socially and culturally connects micro-stories and macro-histories, as has been prioritised here. Qurqumās' case certainly urges us to look at how the endless sets of other micro-stories with which authorial and other voices engaged were made partners in practices of symbolic and physical violence, in discourses of justice and sovereignty, or for that matter in any other structuring, moralizing or legitimating strategies that contributed to the social and cultural making of macro-histories. At the same time, particular authors and their own variegated agencies, relationships and structuring contributions on the different sides of that same middle-ground demand much more, and much more detailed and nuanced, attention. As announced before, all of this arguably also opens up new ways to much more detailed and nuanced understandings of how wider historical processes of political integration, socio-cultural explanation and socio-political formation (or, for that matter, of power, knowledge and time-space) actually played out, intersected, and were productive, especially in the sultanate's 15th century.

As far as the particularity of the relationship between Qurqumās' micro-history and the macro-history of Barsbāy's state is concerned, it may already be concluded that Qurqumās certainly appears on the narrative middle ground of extant contemporary renderings of stories involving him in two interlocking performative capacities. His persona emerges as one of the foremost mediators of not just the practical but also the discursive strategies that were deployed to produce, discipline and structure messy power relationships across Egypt, Syria, East Anatolia and the Hijāz into particular and flexible moulds that generated sufficient levels of political integration, hierarchical coherence and legitimate order to make for the particular success of Barsbāy's state in the social and cultural reality of things. In this particular case of Barsbāy's reign between 1422 and 1438, it appears from Qurqumās' narratives that at least for as long as the timeframe's and court's relational construct and hegemonic discourse were that of Barsbāy's state, its mediators' adventurous and messy trail of local empowerment at changing varieties of social frontiers continued to be ironed out, explained away or downplayed as part and parcel of a longstanding, coherent and legiti- 
mate process that involved the expansion, maintenance and restoration of the sultanate's natural order of justice and sovereignty. However, when that social construct transformed and when that hegemonic discourse shifted - as they did when Barsbāy disappeared from the sultanate's scene of power - the messiness involving actions such as those attributed to Qurqumās acquired new meanings, and these were then operationalised to discursive and practical purposes that had equally shifted. In the case of quite a few agents, partners and mediators of Barsbāy's interests, including Qurqumās, this ended badly, not just in the violent social reality of Syro-Egyptian politics, but also in the equally embattled discursive reality of the sultanate's politics of historical truth.

\section{Bibliography}

\section{Primary sources}

'Abd al-Bāsiț, Zayn al-Dīn b. Khalīl b. Shāhīn al-Malațī (2002), Nayl al-Amal fĩ Dhayl al-Duwal, 'Umar 'Abd al-Salām Tadmurī,ed., 8 vols., Sidon: al-Maktabah al-'așrīyah.

al-'Aynī, Badr al-Dīn (1985-1989), 'Iqd al-Jumān fĩ Tārīkh Ahl al-Zamān, 'Abd al-Rāzīq al-Ṭanțāwī al-Qarmūț, ed., 2 vols., Cairo: al-Zahrā'.

Ibn Ḥajar, Abū al-Faḍl Aḥmad b. 'Alī al-'Asqalānī (1986), Inbā' al-Ghumr bi-Abnā' al- Umr fī l-Tārīkh, Muḥammad 'Abd al-Mu'īd Khān, ed., 9 vols., Beirut: Dār al-kutub al-'ilmīyah. Ibn lyās, Muḥammad b. Aḥmad al-Ḥanafī (2010), Badā’' al-Zuhūr fĩ Waqāi' al-Duhūr, Muḥammad Mușțafá, ed., 5 vols., Beirut: Orient Institut.

Ibn Taghrībirdī, Abū al-Mahāsin Jamāl al-Dīn Yūsuf (1909-1936), al-Nujūm al-Zāhira fĩ Mulūk Mișr wa-l-Qāhira, William Popper, ed., 6 vols., Berkeley: The University of California Press.

- (1963-1972), al-Nujūm al-Zāhira fĩ Mulūk Miṣr wa-l-Qāhirah, Fahīm Muḥammad Shaltūt / Ibrāhīm 'Alī Tarkhān / Jamāl al-Dīn al-Shayyāl, eds., 16 vols., Cairo: al-Hay’a al-miṣrīya al-'āmma li-l-kitāb.

- (1984-2009), al-Manhal al-Ṣāfĩ wa-l-Mustawfī ba'da al-Wāfi', Muḥammad Muḥammad 'Amīn / Nabīl Muḥammad 'Abd al-'Azīz, eds., 13 vols., Cairo: al-Hay'ah al-mișrīyah al-'āmmah li-al-kitāb.

- (1990), Hawāàith al-Duhūr fĩ Madá al-Ayyām wa-l-Shuhūr, Fahīm Muḥammad Shaltūt,ed., Cairo: al-Mațābi‘ al-ahrām al-tijārīyah.

al-Jawharī, 'Alī b. Dāwūd al-Șayrafī (1970-1994), Nuzhat al-Nufūs wa-l-Abdān fĩ Tawārīkh Ahl al-Zamān, Ḥasan Ḥabashī, ed., 4 vols., Cairo: Mațba'at dār al-kutub.

al-Maqrīzī, Taqī al-Dīn Aḥmad b. 'Alī (1956-1972), Kitāb al-Sulūk li-Márifat Duwal al-Mulūk, Muḥammad Muṣțafá Ziyādah / Sa 'īd 'Abd al-Fattāḥ 'Āshūr, eds., 4 vols., Cairo: Dār al-kutub.

al-Sakhāwī, Muḥammad b. 'Abd al-Raḥmān (2003), al-Ḍaw' al-Lāmi' li-Ahl al-Qarn al-Tāsi', 'Abd al-Lațīf Ḥasan 'Abd al-Raḥmān, ed., 12 vols., Beirut: Dār al-kutub al-'ilmīyah. 


\section{Secondary sources}

Adriaenssens, Veerle / Jo Van Steen bergen (2016), “Mamluk Authorities and Anatolian Realities: Jānibak al-Ṣūfī, sultan al-Ashraf Barsbāy, and the Story of a Social Network in the Mamluk/Anatolian Frontier Zone, 1435-1438”, Journal of the Royal Asiatic Society (26/4): 591-630.

APE LLÁNIZ, Francisco J. (2009), Pouvoir et finance en Méditerranée pré-moderne: le deuxième état mamelouk et le commerce des épices (1382-1517), Barcelona: Consejo Superior de Investigaciones Científicas.

ARB ERRY, Arthur J. (1955), The Koran interpreted, London: Allen \& Unwin.

Assmann, Jan (2008), “Communicative and Cultural Memory”, in: Astrid Erll / Ansgar Nünning, eds., Cultural Memory Studies. An International and Interdisciplinary Handbook, Berlin, New York: Walter de Gruyter, 109-118.

Bın BAş, Ilker E. (2016), Intellectual Networks in Timurid Iran. Sharaf al-Dīn 'Alī Yazdī and the Islamicate Republic of Letters, Cambridge: Cambridge University Press.

Blan KINSHIP, Khalid Yahya (2003), “Obedience”, Encyclopedia of the Qur'ān, 1st ed., 3, 566-569.

BouRdieu, Pierre (1994), "Rethinking the State: Genesis and Structure of the Bureaucratic Field”, Sociological Theory 12, 1-18.

Broadbridge, Anne F. (1999), “Academic Rivalry and the Patronage System in FifteenthCentury Egypt: al-'Aynī, al-Maqrīzī, and Ibn Ḥajar al-'Asqalān̄̄”, Mamluk Studies Review 3, 86-107.

- (2003), "Royal Authority, Justice and Order in Society: The Influence of Ibn Khaldūn on the Writings of al-Maqrīzī and Ibn Taghrībirdī”, Mamluk Studies Review 7, no. 2, 231-245.

Соок, Michael (2000), Commanding Right and Forbidding Wrong in Islamic Thought, Cambridge: Cambridge University Press.

Coureas, Nicolas (2013), “Losing the War but Winning the Peace: Cyprus and Mamluk Egypt in the Fifteenth Century”, in: Urbain Vermeulen / Kristof D’Hulster / Jo Van Steenbergen, eds., Egypt and Syria in the Fatimid, Ayyubid and Mamluk Eras VII, Leuven: Peeters, 351-361.

DARLIN G, Linda (2013), A History of Social Justice and Political Power in the Middle East: the Circle of Justice from Mesopotamia to Globalization, New York: Routledge.

DARRAG, Ahmad (1961), L'Égypte sous le règne de Barsbay: 825-841/1422-1438, Damas: Institut français de Damas.

DeкKICHE, Malika (2014-2015), “New Source, New Debate: Re-evaluation of the MamlukTimurid Struggle for Religious Supremacy in the Hijaz (Paris, BnF MS ar. 4440)", Mamluk Studies Review 18, 247-271.

DENNY, Frederick M. (2003), “Corruption”, Encyclopedia of the Qur'ān, 1st edition, 1, 439-440.

Dumolyn, Jan / VAn Steenbergen, Jo (2017), "Studying Rulers and States across FifteenthCentury Eurasia”, in: Jo Van Steenbergen, ed., Trajectories of Late Medieval State Formation. Political Order and Integration across Fifteenth-Century Muslim West-Asia Eurasian Parallels, Connections, Divergences (in preparation).

Ed BuRy, Peter W. (2000), The Kingdom of Cyprus and the Crusades 1191-1374, Cambridge: Cambridge University Press.

Fou CAULT, Michel (1971), L'ordre du discours, Paris: Gallimard.

Franz, Kurt (2008), "The Ayyubid and Mamluk Revaluation of the Hinterland and Western Historical Cartography”, Mamluk Studies Review 12, no. 2, 133-158. 
GARCIN, Jean-Claude (1969), “Le Caire et la province: constructions au Caire et à Qûs sous les Mameluks Bahrides”, Annales Islamologiques 8: 47-61.

GARCIN, Jean-Claude (1974), Un centre musulman de la Haute-Egypte médiévale: Qūṣ, Cairo: Institut français d'archéologie orientale du Caire.

Green blatt, Stephen J. / Gallagher, Catherine (2000), Practicing New Historicism, Chicago: University of Chicago Press.

HIRSCHLER, Konrad (2006), Medieval Arabic Historiography. Authors as Actors, London: Routledge.

- (2012), “Islam: The Arabic and Persian Traditions, Eleventh-Fifteenth Centuries”, in Sarah Foot and Chase F. Robinson, eds., The Oxford History of Historical Writing. Volume 2: 400-1400, Oxford: Oxford University Press, 276-286.

- (2013), "Studying Mamluk Historiography”, in: Stephan Conermann, ed., Ubi sumus? Quo vademus? Mamluk Studies - State of the Art, Bonn: V\&R unipress, Bonn University Press, 159-186.

IRWIN, Robert (2002) “The Privatization of 'Justice' Under the Circassian Mamluks”, Mamluk Studies Review (6): 63-70.

KeAney, Heather N. (2013), Medieval Arabic Historiography: Remembering Rebellion, New York: Routledge.

LoISEAU, Julien (2014), Les Mamelouks: XIIle - XVIe siècle: une expérience du pouvoir dans l'Islam médieval, Paris: Éditions du Seuil.

MARTEL-Thoum IAN, Bernadette (1991), Les civils et l'administration dans l'état militaire mamlūk (IXe/XVe siècle), Damas: Institut français de Damas.

MeloY, John L. (2003), “Imperial Strategy and Political Exigency: The Red Sea Spice Trade and the Mamluk Sultanate in the Fifteenth Century”, Journal of the American Oriental Society (123): 1-19.

- (2010), Imperial Power and Maritime Trade: Mecca and Cairo in the Later Middle Ages, Chicago: Medoc.

MorTEL, Richard T. (1995), “Aspects of Mamlūk Relations with Jedda during the Fifteenth Century: The Case of Timrāz al-Mu'ayyadī”, Journal of Islamic Studies (6): $1-13$.

- (1996), "Grand "Dawādār" and Governor of Jedda: The Career of the Fifteenth Century Mamlūk Magnate Ğānibak al-Ẓāhirī”, Arabica (43 no. 3): 437-456.

ONımus, Clément (2013), "Les émirs dans le sultanat mamelouk sous les sultans Barqūq et Farağ (784-815/1382-1412). Restauration sultanienne et conflits émiraux”, PhD Diss., École Pratique des Hautes Études / Universiteit Gent.

- (2015), "La question du cursus honorum mamelouk au tournant du xiv $-x v^{e}$ siècle”, Bulletin d'études orientales (64): 365-390.

Petry, Carl (1993), Twilight of Majesty: the Reigns of the Mamluk Sultans al-Ashraf Qaytbay and Qansuh al-Ghawri in Egypt, Seattle: University of Washington Press.

Pieters, Jürgen (2000), “New Historicism: Postmodern Historiography between Narratives and Heterology", History and Theory (39/1): 21-38.

RAB BAT, Nasser (2012), “Was al-Maqrīzī’s Khițaṭ a Khaldūnian History?”, Der Islam (89, no. 1-2): 118-140.

RAPOPORT, Yossef (2004), “Invivisible Peasants, Marauding Nomads: Taxation, Tribalism, and Rebellion in Mamluk Egypt”, Mamluk Studies Review (8, no. 2): 1-22.

- (2012), "Royal Justice and Religious Law: Siyāsah and Shari'ah under the Mamluks”, Mamluk Studies Review (16): 71-102. 
Robinson, Chase F. (2012), “Islamic Historical Writing, Eighth through the Tenth Centuries”, in Sarah Foot and Chase F. Robinson, eds., The Oxford History of Historical Writing. Volume 2: 400-1400, Oxford: Oxford University Press, 238-266.

SAFI, Omid (2006), The Politics of Knowledge in Premodern Islam: Negotiating Ideology and Religious Inquiry, Chapel Hill: University of North Carolina Press, 2006.

SAuvaget, Jean (1950), “Noms et surnoms de Mamelouks”, Journal Asiatique 238, 31-58.

SCHEIDEL, Walter (2013), "Studying the State”, in: Peter Fibiger Bang / Walter Scheidel, eds., The Oxford Handbook of the State in the Ancient Near East and Mediterranean, Oxford: Oxford University Press, 5-57.

StEInMETZ, George (1999), “Introduction: Culture and the State”, in: George Steinmetz, ed., State/Culture. State-Formation after the Cultural Turn, Ithaca: Cornell University Press, 1-49.

StILt, Kristen (2011), Islamic Law in Action: Authority, Discretion, and Everyday Experiences in Mamluk Egypt, Oxford: Oxford University Press.

Tilly, Charles (1985), “War Making and State Making as Organized Crime”, in: Peter Evans / Dietrich Rueschemeyer / Theda Skocpol, eds., Bringing the State Back In, Cambridge: Cambridge University Press, 169-191.

Tilly, Charles (1992), Coercion, Capital, and European States AD 990-1992, Cambridge: Blackwell.

VALLET, Eric (2010), L'arabie marchande. État et commerce sous les sultans rasûlides du Yémen (626-858/1229-1454), Paris: Publications de la Sorbonne.

VAn Steen Bergen, Jo (2015), “'Mamlukisation' between Social Theory and Social Practice: An essay on reflexivity, state formation, and the late medieval sultanate of Cairo", ASK Working Paper 22, Annemarie Schimmel Kolleg, Universität Bonn, Bonn. https://www. mamluk.uni-bonn.de/publications/working-paper.

- (2016 a), Caliphate and Kingship in a Fifteenth-century Literary History of Muslim Leadership and Pilgrimage. A Critical Edition, Annotated Translation, and Study of al-Maqrīzī's Al-Dֵahab al-Masbūk fī Dikr man Ḥağğa min al-Hulafā' wa-l-Mulūk, Leiden: Brill.

- (2016 b), “Appearances of Dawla and Political Order in late medieval Syro-Egypt. The state, social theory, and the political history of the Cairo Sultanate (thirteenth-sixteenth centuries)", in: Stephan Conermann, ed., History and Society during the Mamluk Period (1250-1517). Studies of the Annemarie Schimmel Research College II, Bonn: V\&R unipress, Bonn University Press, 53-87.

- (in press), "Revisiting the Mamluk Empire. Political Action, Relationships of Power, Entangled Networks, and the Sultanate of Cairo in Late Medieval Syro-Egypt”, in: Reuven Amitai / Stephan Conermann, eds., The Mamluk Empire and its Neighbours, Bonn: V\&R unipress, Bonn University Press.

Van Steenbergen, Jo / Wing, Patrick / D’hulster, Kristof (2016 a), “The Mamlukization of the Mamluk Sultanate? State Formation and the History of Fifteenth Century Egypt and Syria: Part I - Old Problems and New Trends”, History Compass 14, no. 11, 549-559.

- (2016 b), "The Mamlukization of the Mamluk Sultanate? State Formation and the History of Fifteenth Century Egypt and Syria: Part II - Comparative Solutions and a New Research Agenda", History Compass 14, no. 11, 560-569.

WIET, Gaston (1960), “Barsbāy”, Encyclopaedia of Islam, 2nd ed. (reprint), 1, 1053-1054.

WING, Patrick (2007), “The Decline of the Ilkhanate and the Mamluk Sultanate's Eastern Frontier”, Mamluk Studies Review (11, no. 2): 77-88. 
WING, Patrick (2014), “Indian Ocean Trade and Sultanic Authority: The Nāziir of Jeddah and the Mamluk Political Economy”, Journal of the Economic and Social History of the Orient (57): 55-75.

- (2015), "Submission, Defiance, and the Rules of Politics on the Mamluk Sultanate's Anatolian Frontier", Journal of the Royal Asiatic Society Third Series (25): 377-388.

Woods, John E. (1999), The Aqquyunlu. Clan, Confederation, Empire, Salt Lake City: University of Utah Press. 